\title{
Dendritic inhibition by Shh signaling-dependent stellate cell pool is critical for motor learning
}

\author{
Wen Li ${ }^{1 \#}$, Lei Chen ${ }^{1 \#}$, Jonathan T. Fleming ${ }^{1}$, Emily Brignola ${ }^{1}$, Kirill Zavalin², Andre H. \\ Lagrange $^{2}$, Tonia S. Rex ${ }^{3}$, Shane A. Heiney ${ }^{4}$, Gregory J. Wojaczynski ${ }^{5}$, Javier F. Medina ${ }^{5}$ and \\ Chin Chiang ${ }^{1 *}$
}

${ }^{1}$ Department of Cell and Developmental Biology, Vanderbilt University School of Medicine, 4114 MRB III, Nashville, TN 37232

${ }^{2}$ Department of Neurology, Vanderbilt University Medical Center, 6135 MRB III, Nashville, TN 37232

${ }^{3}$ Department of Opthalmology \& Visual Science, Vanderbilt Eye Institute, 11435 MRBIV, Nashville, TN 37232

${ }^{4}$ Iowa Neuroscience Institute, University of Iowa, Iowa City, IA 52242

${ }^{5}$ Department of Neuroscience, Baylor College of Medicine, S709 Houston, TX 77030

Running title: Molecular layer interneuron subtype

Keywords: Cerebellum, neurogenesis, Sonic hedgehog, interneuron subtypes, dendritic synapses and motor learning.

\#These authors contributed equally

*Address all correspondence to: Chin Chiang

chin.chiang@vanderbilt.edu

Tel: (615) 343-4922 


\section{SUMMARY}

Cerebellar inhibitory interneurons are important regulators of neural circuit activity for diverse motor and non-motor functions. The molecular layer interneurons (MLI), consisting of basket cells (BCs) and stellate cells (SCs), provide dendritic and somatic inhibitory synapses onto Purkinje cells, respectively. They are sequentially generated in an inside-out pattern from Pax $2+$ immature interneurons which migrate from the prospective white matter to the ML of the cortex. However, little is known as to how MLI subtype identities and pool sizes are determined, nor are their contributions to motor learning well understood. Here, we show that GABAergic progenitors fated to generate both BCs and SCs respond to the Shh signal. Conditional abrogation of Shh signaling inhibited proliferation of GABAergic progenitors and reduced the number of Pax $2^{+}$cells, whereas persistent Shh pathway activation increased their numbers. These changes, however, did not affect early-born BC numbers but selectively altered the SC pool size. Moreover, genetic depletion of GABAergic progenitors when BCs are actively generated also resulted in a specific reduction of SCs, suggesting that the specification of MLI subtypes is independent of Shh signaling and their birth order and likely occurs after Pax $2^{+}$cells settle into their laminar positions in an inside-out sequence. Mutant mice with reduced SC numbers displayed decreased dendritic inhibitory synapses and neurotransmission onto Purkinje cells, resulting in an impaired acquisition of eyeblink conditioning. These findings also reveal an essential role of Shh signaling-dependent SCs in regulating inhibitory dendritic synapses and motor learning.

\section{INTRODUCTION}

The cerebellum plays an essential role in fine motor learning characterized by an adaptive process that involves recurring error-evoked learning to maintain optimum motor performance (Raymond \& Medina, 2018). The circuit that enables this mode of learning is comprised of different classes 
of inhibitory and excitatory neurons that are generated during embryonic and postnatal development from spatially distinct progenitors (Palay \& Chan-Palay, 1974a; Zhang \& Goldman, 1996; Wang et al, 2005; Machold \& Fishell, 2005; Hoshino et al, 2005). However, it remains unclear how their identities and numbers are specified to generate a functional circuit.

Purkinje cells (PCs) are the sole projection neurons in the cerebellar cortex, with a dendritic plane in the molecular layer where they integrate excitatory and inhibitory input from different sources (Beckinghausen \& Sillitoe, 2018). The principal excitatory neurons are granule cells with their axons extending into the molecular layer as parallel fibers that provide excitatory input to PCs. Additionally, PCs receive excitatory input from two classes of extracerebellar afferent projections; climbing fibers of the inferior olive nuclei terminate in the molecular layer and contact PCs, and mossy fibers (from the brainstem and elsewhere) synapse with granule cells and thus influence many PCs at once. The balance to the excitatory neurotransmission is provided largely by GABAergic inhibitory inputs from molecular layer interneurons (MLIs) that consist of basket cells (BCs) and stellate cells (SCs) (Sotelo, 2015). BCs are located in the inner one-third of the ML, and their axons form perineuronal nests or "baskets" as well as specialized structures known as pinceau around the PC soma/axon initial segment (Somogyu \& Hámori, 1976). In contrast, SCs occupy the rest of the ML and make direct contact with distal PC dendrites. Despite the apparent morphological and positional differences between BCs and SCs, the precise location and the boundary between these two cell types have not been well defined until the recent identification of Ret, a receptor tyrosine kinase, whose expression is restricted to BCs (Sergaki et al, 2017).

Cerebellar inhibitory neurons are generated from spatially distinct germinal zones. In mice, the early-born neurons, including PCs, Golgi (granule layer interneuron), and Lugaro cells, are generated from the ventricular zone (VZ) of the fourth ventricle during early to mid-embryonic 
stages (Hoshino et al, 2005; Sudarov et al, 2011). The late-born MLIs are generated sequentially but in an overlapping manner from the prospective white matter (PWM) during the late embryonic to postnatal development, with BCs emerging first and followed by SCs (Zhang \& Goldman, 1996). Recent studies have identified stem cell-like astroglia in the PWM as the source of transient amplifying GABAergic progenitors marked by Ptf1a (Fleming et al, 2013), a bHLH transcription factor whose function is required for the specification of all GABAergic lineages, including Pax $2^{+}$ immature interneuron (Hoshino et al, 2005; Pascual et al, 2007). Pax2+ cells migrate from PWM to ML before terminally differentiating into BCs and SCs (Weisheit et al, 2006). However, it remains unclear as to how MLI subtype identities are determined.

The Shh signaling pathway has been shown to play critical roles during cerebellar development. It is required for the rapid expansion of granule cells by promoting the proliferation of granule cell precursors (Dahmane \& Altaba, 1999; Wallace, 1999; Wechsler-Reya \& Scott, 1999). Additionally, Shh signaling is transiently required to maintain the proliferative capacity of multipotent radial glial cells in the VZ and astroglia in the PWM (Huang et al, 2009; Fleming et al, 2013). Unlike VZ, Ptfla+ progenitors are proliferative and exhibit Shh pathway activity in the PWM (Fleming et al, 2013). However, the significance of this activity in the regulation of MLI pool size and cerebellar function has not been determined. While recent studies have shown that MLIs play an important role in cerebellar-dependent motor learning (Brinke et al, 2015; Sergaki et al, 2017), it remains to be determined as to what extent each MLI subtype contributes to motor learning. In this study, we investigated the role of Shh signaling and its contribution to MLI subtype allocations and cerebellar-dependent motor learning.

\section{RESULTS}

Shh signaling is transiently activated in Ptf1a+ progenitors in the PWM 
To better define Shh signaling in GABAergic progenitors, we used $\beta$-galactosidase ( $\beta$-gal) expression from Gli $^{\text {nlacz }}$ mice (Bai et al, 2002) to assess Shh pathway responsiveness among Ptf1a ${ }^{+}$ cells at different postnatal stages. We found that Shh signaling is transiently activated in a subset of Ptf1a+ cells from P1 to P8 (Figure 1A), while contemporaneous populations of Ptf1a ${ }^{+}$cells in the brain/ brainstem were negative for the signal. At P1, the $\beta-G a l+$ and Ptf1a+ cells account for $~ 19 \%$ of Ptfla+ progenitors in the PWM, and this number increased to $26 \%$ at P3 (Figure 1B and 1C). However, at P6, the percentage of double-positive cells declined to $\sim 14 \%$, but no statistically significant changes were observed for Ptfla+ progenitors (Figure 1B and 1C). By P8, a very small population of Ptfla+ progenitors were positive for $\beta$-gal expression (Figure 1C). Thus, the Shh pathway is transiently activated in a subset of $\mathrm{Ptf}_{1} \mathrm{a}^{+}$progenitors.

To ascertain the significance of Shh signaling in $\mathrm{Ptf}_{1} \mathrm{a}^{+}$progenitors, we blocked Shh reception by genetically ablating the transducer Smo using the GABAergic lineage-specific Ptfla $a^{\text {cre }}$ line (Kawaguchi et al, 2002). Our initial analysis of the mature cerebellar cortex of Ptfla ${ }^{C r e}$; Smo ${ }^{F /-}$ mutant mice at P30 detected no structural or layering alterations; thickness of the molecular layer, granule layer, overall cerebellar area, and foliation pattern was comparable to the control (Figure 1D-1F). However, there is a clear reduction of hematoxylin/eosin-stained cells in the molecular layer. Indeed, immunohistochemical (IHC) detection of the calcium-binding protein, parvalbumin, which preferentially marks MLIs and PCs, showed a statistically significant decrease in the total number of MLIs in Ptfla ${ }^{C r e}$; $\mathrm{Smo}^{\mathrm{F/}}$ mutant cerebella (Figure $1 \mathrm{D}$ and $1 \mathrm{G}$ ). The most reduction was most prominent in the outer half of the ML, suggesting that a germinal program was biased towards the stellate interneuron subtype (see below). The number of other early-born inhibitory neurons, including deep cerebellar nuclei (DCN), PCs and Golgi cells expressing GABA, Calbindin and 
Neurogranin, respectively, was not significantly changed in $P t f l a^{C r e} ; S_{m o}^{F /}$ mutants (Figure $\left.1 \mathrm{H}-1 \mathrm{~J}\right)$. Additionally, no significant changes in Purkinje cell spine density were observed (Figure $1 \mathrm{~K}$ ).

\section{Shh signaling regulates precursor pool expansion}

To understand how Shh signaling affects the MLI pool size, we evaluated the proliferation and survival of Ptf1a progenitors in the PWM. Following a short-term (1h) labeling with the thymidine analog EdU, we observed a significant reduction of proliferating Ptf1a progenitors in Ptfla ${ }^{C r e}$; $S_{m o}{ }^{F /}$ mutants at both P3 ( 20\%) and P6 ( 34\%) when compared to controls in the vermis (Figure $2 \mathrm{~A}-2 \mathrm{C})$. Accordingly, the total number of Ptfla+ progenitors in the mutant was reduced by $\sim 30 \%$ and $\sim 68 \%$ at P3 and P6, respectively (Figure $2 \mathrm{~B}$ and $2 \mathrm{C}$ ). The proliferative effect of Shh signaling on Ptfla+ progenitors was not restricted to the vermal region, as a similar reduction $(\sim 39 \%)$ was also observed in parasagittal sections at P6 (Figure S1). Viability was measured with cleavedCaspase-3, but no appreciable apoptotic cells were found in Ptf1a lineage cells at either P3 or P6 (Figure S2).

Genetic fate-mapping studies have shown that $\mathrm{Ptfla}^{+}$cells emerge upstream of and contribute considerably to neonatal $\mathrm{Pax} 2^{+}$immature interneuron pools (Fleming et al, 2013). The peak of Pax 2 production in PWM occurs at P5, where they subsequently migrate to ML through the inner granule layer (IGL) before terminally differentiating into BCs and SCs (Weisheit et al, 2006; Wefers et al, 2018). We measured the abundance of Pax2+ cells at P6 and observed a significant reduction of their numbers in PWM, IGL, and ML (Figure 2D-H).

The role of Shh signaling in promoting Ptf1a progenitor proliferation was further evaluated using a gain-of-function approach. We generated Ptfla $a^{\text {cre }}$ S SmoM2 mice by crossing the Ptfla ${ }^{\text {Cre }}$ driver strain to SmoM2 conditional mutants that harbor a constitutively activated form of Smo 
(Mao et al, 2006). Consistent with the loss of function study, we observed a significant increase in the number of Ptf1a+ progenitors $(\sim 27 \%)$ as well as their proliferative capacity $(\sim 15 \%)$ in $P t f 1 a^{\text {cre }}$; SmoM2 cerebella when compared to controls at P6 (Figure 2I-2K). Accordingly, the number of Pax $2+$ cells is also significantly increased (Figure $2 \mathrm{~L}$ and $2 \mathrm{M}$ ). Together, we provide strong evidence for a direct and essential role of Shh signaling in driving the proliferation of Ptf1a+ progenitors in PWM and subsequent expansion of Pax2+ immature interneurons.

Previous studies have shown that Cyclin d2 (Ccnd2) is expressed in the PWM and required for the proliferation of MLI progenitors (Huard et al, 1999), but the signal that activates its expression is unknown. We therefore examined Ccnd 2 expression and found that the number of Ccnd2+ GABAergic progenitors is significantly reduced in the Ptfla ${ }^{\mathrm{Cre}} ; \mathrm{Smo}^{\mathrm{F} / \mathrm{PWM}}$ by immunohistochemistry (Figures. $2 \mathrm{O}$ and 2P). These data suggest that Shh signaling regulates Ccnd2 expression that contributes to proliferation of Ptf1a progenitors.

\section{Specification of MLI subtypes occurs independent of their birth orders}

To precisely determine whether specific MLI subtypes are affected in $\mathrm{Ptfla}^{\mathrm{Cre}}$; Smo ${ }^{\mathrm{F} / \text { mutants, we }}$ acquired the $\operatorname{Ret}^{G F P}$ mouse line in which EGFP reporter is expressed from the endogenous Ret promoter (Jain et al, 2006). Consistent with previous studies (Sergaki et al, 2017), Ret ${ }^{G F P}$ expression in BCs is first detectable at P7 and continues throughout adulthood (Figure S3A). Outside of the ML, $\operatorname{Ret}^{G F P}$ is expressed in the deep cerebellar nuclei (DCN) and associated fibers in PWM (Figure S3B and S3C), but not in Pax2+ interneuron progenitors as reported previously (Sergaki et al, 2017). The Ret+ DCN neurons are NeuN positive but GABA negative, indicating that they are not GABAergic neurons (Figure S3D). Therefore, Ret $^{G F P}$ expression is confined to mature BCs and DCN neurons. In addition to $\operatorname{Ret}^{G F P}$ expression, we incorporated Parvalbumin (Parv) as a marker to 
highlight all MLIs. In this way, BCs and SCs can be unambiguously identified as $\operatorname{Ret}^{\mathrm{GFP}+} \operatorname{Parv}^{+}$and $\operatorname{Ret}^{\mathrm{GFP}-}$ Parv $^{+}$cells, respectively. Using these markers, we were able to determine that SC numbers were reduced by $\sim 21 \%$ in Ptfla ${ }^{C r e}$; Smo ${ }^{F /-}$ mutant cerebella (Figure 3A and 3B) whereas no appreciable changes in BC numbers were observed when compared to that of controls (Figure 3A and $3 \mathrm{C})$.

Classical birthdating and genetically inducible fate mapping (GIFM) studies have suggested that MLI subtype identities are correlated with their birth dates and laminar positions within the cerebellar cortex (Leto et al, 2006; Sudarov et al, 2011). To determine if the subtype-specific effect of Shh signaling on MLIs is associated with temporal differences in Shh responsiveness of Ptf1a progenitors fated to generate both BCs and SCs, we generated Ptfla $a^{\text {creER }}$; Ai9; Ret ${ }^{G F P}$ line to perform GIFM study focusing on critical stages where Shh signaling is activated in Ptfla progenitors. Tamoxifen (TM) administration at P0 marked both BCs $\left(\mathrm{dtTomato}^{+}\right.$Ret $\left.^{\mathrm{GFP}}{ }^{+}\right)$and $\mathrm{SCs}\left(\mathrm{dtTomato}^{+}\right.$ $\operatorname{Ret}^{\mathrm{GFP}-}$ ) in the molecular layer at P21, representing $\sim 21 \%$ and $\sim 79 \%$ of all marked cells, respectively (Figure 3D, 3E and 3F). Moreover, marked BCs account for $\sim 56 \%$ of all Ret ${ }^{\mathrm{GFP}+}$ cells (Figure 3G), indicating that the peak of BC production occurs between P0 and P1. When TM was administered at P3, marked BCs decreased to $\sim 30 \%$ (Figure 3G), with a concomitant increase in marked SCs (Figure 3F). At P5, SCs are the only labeled population present in the ML (Figure 3F and 3G). Therefore, BCs and SCs are both generated at the time when Shh signaling is active in Ptflat progenitors, consistent with previous Gli ${ }^{\text {CreER }}$ GIFM studies in which BC and SC subtypes are both generated from Shh-responsive progenitors (Fleming et al, 2013). Therefore, the differential effect of Shh signaling on MLI subtypes is unlikely due to temporal or regional difference in Shh responsiveness. Indeed, analysis of Ptfla ${ }^{\text {cre }}$; SmoM2 mutants with constitutive Shh pathway 
activation in $\mathrm{Ptfla}^{+}$progenitors showed that only $\operatorname{Ret}^{\mathrm{GFP}-} \operatorname{Parv}^{+}(\mathrm{SC})$ numbers are elevated whereas the $\operatorname{Ret}^{\mathrm{GFP}+} \mathrm{Parv}^{+}(\mathrm{BC})$ pool remained unchanged when compared to the control (Figure 3H-K).

The observation that altered numbers of $\mathrm{Pax} 2^{+}$immature interneurons in the gain and loss of Shh signaling mutants had no effect on BC pool size suggests commitment to the BC fate from Pax2+ cells does not occur until they settle into the inner ML. Accordingly, the BC pool remains unchanged as long as there are sufficient Pax2+ cells to fill the inner ML. To further test this model, we generated Ptfla ${ }^{\text {cre }}$; Ret ${ }^{G F P} ; \operatorname{ROSA26^{DTR}}$ mice designed to temporarily ablate Ptf1a $\mathrm{a}^{+}$progenitors and their descendent Pax2 $2^{+}$cells. The ROSA26 $6^{D T R}$ line expresses the Cre-inducible Diptheria toxin receptor (DTR) that triggers cell ablation upon exposure to Diptheria toxin (DT). Administration of DT at P0-P2, a time when Ptf1 $\mathrm{a}^{+}$progenitors are fated to generate most BCs, resulted in a drastic reduction of $\mathrm{Pax}^{+}$immature interneurons in all layers of the cerebellum at P6 (Figure 3L-3P). Despite $\sim 50 \%$ reduction of total Pax $2^{+}$cells (Figure $3 \mathrm{M}$ ), we observed no effect on BC numbers while SCs are reduced by $\sim 49 \%$ at P21 (Figure 3Q - 3T). The lack of perturbations in BC numbers is not due to selective depletion of $\mathrm{Ptfl}^{+} \mathrm{a}^{+}$progenitors at the later time period when SCs are generated as evidenced by more than $27 \%$ reduction of Ptf $1 \mathrm{a}+$ progenitors at $\mathrm{P} 2$ when DT was administered at P0 and P1 (Figure S4). We also ruled out the possibility of a delay in BCs to SCs production in DT treated mice, which would have prolonged BCs production and preferentially affected SC numbers. For this, we performed classical birthdating study on DT treated pups (P0-P2) by administrating EdU at P5 when BCs are no longer generated (Figure 3D-G). Analysis of EdU labeled cells at P21 revealed that only SCs $\left(\operatorname{Ret}^{-} \mathrm{Parv}^{+}\right)$but no BCs $\left(\operatorname{Ret}^{+} \mathrm{Parv}^{+}\right)$were labeled after DT treatment (Figure S4), indicating that the progenitor cell ablation did not elicit a delay in BCs to SCs production. Collectively, the results suggest that MLI subtypes are specified independent of their birth order but 
likely occur at their laminar positions, providing a mechanism by which Shh signaling is selectively promoting the expansion of SCs.

\section{Impaired GABAergic synapses and inhibitory control over PCs}

In the mature cerebellum, SCs and BCs relay inhibitory input to PCs via direct synapses on dendritic tree or somata/proximal initial segment, respectively, balancing excitatory input received from granule neurons and afferent fibers (Sotelo, 2015). To understand how the loss of Shh-dependent SCs might impact the integrity of cerebellar neural circuitry, we evaluated the distribution of specific molecular markers for inhibitory and excitatory synapses in the ML. We used a presynaptic marker, vesicular GABAergic transporters (VGAT), in combination with a postsynaptic marker Gephyrin to highlight inhibitory synapses. In the ML, the number of inhibitory synapses (puncta with colocalization) at PC dendrites was reduced by $31 \%$ in Ptfla ${ }^{\mathrm{Cre}}$; $\mathrm{Smo}^{\mathrm{F} /}$ - mutants compared to controls (Figures 4A-4C). We also used another inhibitory presynaptic marker, glutamic acid decarboxylase 67 (Gad67), which is responsible for up to $90 \%$ of GABA synthesis in the brain (Asada et al, 1996; Kash et al, 1997), and found that its puncta are also significantly reduced (Figure S4). Consistent with unperturbed $\mathrm{BC}$ development, the number of inhibitory synapses at PC soma and the pinceau marked by the potassium voltage-gated channel $1.2(\mathrm{Kv} 1.2)$ remains similar between $P t f 1 a^{C r e} ; S^{F /-}$ mutants and controls (Figures 4D and 4E). However, VGluT1 (Figures 4F and 4H), which labels excitatory synaptic terminals at granule cell parallel fibers, showed no significant changes, nor did VGluT2 (Figures 4G and 4I), which marks excitatory synaptic terminals at climbing fibers. Altogether these findings show substantial impairment to the inhibitory component of the cerebellar system in $\mathrm{Ptfla}^{\mathrm{Cre}}$; Smo ${ }^{\mathrm{F} /-}$ mutants, while the excitatory component appears to be unperturbed. 
The significantly reduced number of dendritic inhibitory synapses in $\mathrm{Ptfla}^{\mathrm{Cre}}$; $\mathrm{Smo}^{\mathrm{F/}}$ mice suggests impaired neurotransmission. To directly test this, we performed whole-cell patch-clamp recordings on cerebellar slices to compare spontaneous inhibitory postsynaptic currents (sIPSCs) of PCs as a measure of inhibitory synaptic strength in wild-type $(n=10)$ and mutant $(n=8)$ mice. This analysis revealed that adult Ptfla $\mathrm{Cre}^{\mathrm{r}}$ S $\mathrm{Smo}^{\mathrm{F/}-}$ mice had about a $35 \%$ decrease in the frequency of sIPSCs when compared to the control (Figure 5A-5C). Similarly, the amplitude of sIPSCs is also significant reduced in $\mathrm{Ptfla} \mathrm{Cre}^{\mathrm{S}}$ Smo ${ }^{\mathrm{F}-}$ mice (Figure 5B). These findings indicate that PCs lose dendritic synapses and show attenuated inhibitory input.

\section{Diminished capacity for associative motor learning}

To determine whether the reduction of dendritic inhibitory neurotransmission on PCs might impair cerebellum-dependent functions, a series of neurobehavioral assays were performed. The cerebellum is classically known to coordinate motor function, and the most obvious manifestation of cerebellar impairment is abnormal gait. Ptfla ${ }^{C r e} ; S m o^{F /-}$ mice did not demonstrate gross impairments in mobility, such as ataxia, nor were they observed to show clinical signs of tremor. When subjected to treadscan analysis, adult Ptfla ${ }^{\mathrm{Cre}} ; \mathrm{Smo}^{\mathrm{F/}}(\mathrm{n}=12)$ and control mice $(\mathrm{n}=11)$ showed comparable gait, which is divided into three basic components: i) stance (break + propulsion), ii) swing, and iii) stride (stance + swing), and is measured in both length and time (Figures 6A-6E). To test motor learning, these animals were also subjected to an accelerating rotarod assay. On the first day of testing sessions, mutant and control animals showed nearly identical latency to fall, indicating that no obvious differences in motor coordination, balance, or strength were detectable (Figure 6F). However, during the subsequent days, it appeared that Ptfla ${ }^{\mathrm{Cre}}$; $\mathrm{Smo}^{\mathrm{Fl}-}$ mutants had an apparent deficiency in the ability to learn to perform this task, with 
statistically significant shorter latencies to fall than controls (Figure 6F). Overall, loss of a SC subset did not appear to adversely impact gross motor function in $\mathrm{Ptfla}^{\mathrm{Cre}} ; \mathrm{Smo}^{\mathrm{Fl} \text { - }}$ mutants and only imparted a subtle impairment to primitive motor learning.

Proper cerebellar function is also necessary for delay eyeblink conditioning, a form of associative motor learning required for multi-sensory integration that is often impaired in autistic individuals (Medina et al, 2000; Sears et al, 1994). The paradigm involves pairing a neutral conditioned stimulus (CS; e.g., LED light pulse or tone) with an eyeblink-evoking unconditioned stimulus (US; e.g., an air puff). After repeated CS-US pairing, an association is progressively established such that the eyelid conditioned response (CR), in the form of learned blink, occurs before the onset of the US. We, therefore, determined whether cerebellum-dependent eyeblink conditioning is compromised in $P t f l a^{C r e} ; \mathrm{Smo}^{F /-}$ mice with reduced SC numbers. In this paradigm, a blue LED light pulse was used as the CS for a period of $240 \mathrm{~ms}$ followed immediately by a gentle air puff for $40 \mathrm{~ms}$ (Figure 6G). Eyelid movement was measured using a high-speed infrared camera interfaced with MATLAB (Heiney et al, 2014) and the eyelid position was assigned to a value between 0 (fully open) and 1 (fully closed). After 14 days of consecutive sessions of conditioning (1400 trials in total), Ptfla ${ }^{C r e} ; S_{m o}^{F /-}$ mice had a consistently lower amplitude of eyelid closure just before CS exposure when compared to control mice (Figure 6H and 5S). Although both the mutant and control mice showed a gradual increase in the percentage of CRs, mutant mice had significantly lower CRs throughout the conditioning sessions (Figure 6I).

While the Shh pathway has not been reported to be active in the retina of Ptf1a-expressing cells and their lineage, we were concerned that the CR deficit in $\mathrm{Ptfla}^{\mathrm{Cre}}$; $\mathrm{Smo}^{\mathrm{F/}-}$ mutants is due to compromised retina function. We, therefore, performed electroretinograms (ERG) and visual evoked potentials (VEP) to assess retinal and visual pathway activity in response to light. We 
observed no significant differences in maximum responses of rod photoreceptors $\left(\mathrm{a}_{\max }\right)$, inner retinal neurons ( $\mathrm{b}_{\max }$ and oscillatory potentials; OP), or the visual cortex (VEP N1) between Ptfla ${ }^{\text {Cre }}$; $\mathrm{Smo}^{\mathrm{F/}}$ and control mice (Figure S6), indicative of normal retinal and visual pathway function. To confirm that the mutants have a deficit in associative motor learning, we also used a tone as CS in delayed eyeblink conditioning. Similar to LED light, the mutant mice showed a diminished response to the tone as presented by the lower amplitude of eyelid closure and percentage of CRs (Figure 6J, 6K, S5). Collectively, these results indicate that Shh signaling-dependent dendritic synapses formation plays a critical role in associative motor learning.

\section{DISCUSSION}

MLIs constitute the majority of inhibitory interneurons in the cerebellum, but the mechanisms that regulate their subtype identities and pool sizes remain not well understood. We reveal that Shh signaling is activated in a subset of interneuron progenitors that give rise to both BCs and SCs, but surprisingly it is selectively required for the expansion of the SC pool. Through lineage tracing, genetic gain and loss of function, and cell ablation experiments, we show that molecular layer interneuron subtypes are specified independent of Shh signaling and their birth orders but appear to occur in their terminal laminar positions according to inside-out sequence. Our studies at the synaptic and behavioral levels show that dendritic GABAergic inhibition controlled by Shh signaling-dependent SC pools is critical for motor learning.

Previous studies have shown that MLIs originate from multipotent astroglia in the PWM (Fleming et al, 2013; Parmigiani et al, 2015; Silbereis et al, 2009). These astroglia act as resident stem-like cells and proliferate in response to the Shh signal from PCs to generate astrocyte precursors as well as Ptf1a progenitors (Fleming et al, 2013). Our finding that Shh signaling is 
directly required for the proliferation of Ptfla+ progenitors and subsequent expansion of MLIs offers an additional mechanism by which Shh regulates MLI pool size.

It is estimated that approximately $90 \%$ of all inhibitory neurons in the cerebellum are represented by late-born GABAergic interneurons (Weisheit et al, 2006). These neurons come from Pax2-expressing immature interneurons that are mostly generated during the first week of postnatal life (Weisheit et al, 2006). As $\mathrm{Pax}^{+}$cells descend from $\mathrm{Ptfla}^{+}$progenitors (Fleming et al, 2013) and emerge at the final progenitor cell division, Shh-induced proliferation of Ptfla+ progenitors, therefore, serves as the main driver for their rapid expansion. This mode of regulation is in contrast to other regions of the nervous system where Shh pathway activity is generally excluded from postmitotic Ptfla expressing cells. In the spinal cord, Ptfla expression is restricted to the postmitotic progenitors in the dorsal neural tube whereas the Shh pathway is activated in the ventral domain (Glasgow et al, 2005; Bai et al, 2004). Moreover, ectopic Ptfla expression is correlated with the downregulation of the Shh signaling pathway as observed in Danforth's short tail mice (Orchard et al, 2018). Similarly, in the developing retina, Shh signaling is activated in early retinal progenitors whereas Ptfla expression is restricted to postmitotic horizontal and amacrine cells (Fujitani et al, 2006). Indeed, the lack of Shh pathway activity in postmitotic retinal lineage cells is consistent with the absence of visual impairment in $\mathrm{Ptfla}^{\mathrm{crel}+}$; $\mathrm{Smo}^{\mathrm{F/}}$ mice (Figure S5). Therefore, the Shh signaling pathway appears to be co-opted for the rapid expansion of Ptfla ${ }^{+}$ progenitors to ensure an adequate supply of MLIs. Mechanistically, Ccnd2 is an attractive target that mediates the proliferative effect of Shh pathway activation on MLI progenitors. Unlike Ccnd1, Ccnd2 is strongly expressed in MLI progenitors and loss of Ccnd2 impairs their production (Huard et al, 1999). Reduced expression of Cend2 in Smo-deficient Ptfla progenitors is consistent with the Shh pathway regulating Ccnd2 expression. 
It has been reported that cerebellar MLIs undergo limited programmed cell death during the first two weeks of postnatal development (Yamanaka et al, 2004). More recent studies showed that GDNF signaling is required for the survival of MLIs. Genetic deletion of GDNF receptor GFRa1 or Ret in GABAergic progenitors resulted in a $\sim 25 \%$ reduction of MLIs (Sergaki et al, 2017). Interestingly, the loss of NeuroD2, a bHLH transcription factor required for MLI differentiation, also promotes MLI survival (Pieper et al, 2019). Thus, MLI pool size is regulated at multiple levels by distinct mechanisms, from the proliferation of multipotent astroglia and Ptfla progenitors to the survival of MLIs.

Fate mapping and heterochronic transplantation studies have suggested that MLI identities and laminar placement link to birthdate within the cerebellar cortex (Altman \& Bayer, 1997; Cameron et al, 2009; Leto et al, 2009; Sudarov et al, 2011). Accordingly, a reduction in Ptf1a+ progenitors and Pax2+ immature interneurons as observed in $\mathrm{Ptfla}^{\mathrm{crel+}} ; \mathrm{Smo}^{\mathrm{F/}-}$ mutants would have a profound effect on the production of both BCs and SCs. It is, therefore, unexpected to discover that Ptfla ${ }^{\text {cre/+}} ; \mathrm{Smo}^{F /-}$ mutants did not affect BC production. This is not due to a lack of Shh responsiveness of Ptfla+ progenitors fated to generate BCs as our Ptfla ${ }^{\text {CreER }}$ GIFM study showed that BCs are largely generated from P0 to P3 when the majority of Shh responsive Ptf1a+ progenitors are present. Importantly, Gli1 ${ }^{\text {CreER }}$ GIFM studies have shown that both MLI subtypes are generated from Shh-responsive progenitors (Fleming et al, 2013). The fact that the increased Pax2+ cell number observed in Ptfla ${ }^{\text {cre/+}} ;$ SmoM2 mutants did not affect BC pool size further suggests that the commitment to $\mathrm{BC}$ and $\mathrm{SC}$ fates is not directly related to their birth order but appears to occur at laminar positions in an inside out sequence. Accordingly, Pax $2^{+}$cells that initially populate the inner ML acquire BC identity whereas those remaining in the outer ML assume SC fate. This model is further supported by our genetic ablation experiment in which the 
reduction of Ptf1a+ progenitors at the peak of $\mathrm{BC}$ production did not affect $\mathrm{BC}$ numbers despite a drastically diminished number of Pax $2^{+}$cells. We have ruled out the possibilities that the lack of $\mathrm{BC}$ perturbation is due to a delay in the progenitor cell depletion or timing of $\mathrm{BC}$ to SC production. Thus, changes in Pax2+ pool sizes as observed in Smo gain and loss-of-function mutants will have the greatest impact on SC numbers. Our model is consistent with the plastic nature of cerebellar immature interneurons observed from heterochronic transplantation studies(Leto et al, 2009), in which P7 interneurons grafted to P1 cerebella exclusively adopt basket cell fate. Our model also explains why the preferential reduction of SCs in the ML is observed in Ccnd2 and Ascl1 mutants despite an early loss of interneuron progenitors (Huard et al, 1999; Sudarov et al, 2011).

Recent studies have shown that immature GCs play an instructive role in differentiation of SCs at the ML (Cadilhac et al, 2021). At present, Ret is the only marker that is selectively expressed in the BCs. Thus, understanding how its expression is activated may provide insight into how laminar positional information affects BC's identity. Ret has been studied extensively in the context of kidney and enteric nervous system development (Lake \& Heuckeroth, 2013; Costantini, 2016). Its expression in the ureteric bud and enteric neural crest-derived precursor cells is activated by retinoic acid (RA) signaling (Mendelsohn et al, 1999; Simkin et al, 2013). However, analysis of RA signaling using RA responsive reporter mice indicated that it is only activated in a subset of PCs, not in the BCs (Figure S7). Another possibility is that BCs identity is specified through an activity-dependent mechanism as proposed for the cortical interneuron specification (Wamsley \& Fishell, 2017). There is evidence that the patterning of BC pinceau is shaped by PC activity (Zhou et al, 2020). In this context, Ret expression may be activated when the pinceau is established between its axon collaterals and the PC axon initial segment (AIS). Future studies are required to determine how positional information influences BC identity. 
Previous studies have shown that the reduction of MLIs or the loss of their postsynaptic receptors $\gamma 2$ GABA-A resulted in an impaired motor learning (Sergaki et al, 2017; Wulff et al, 2009; Brinke et al, 2015). However, it is unclear to what extent each MLI subtype contributes to motor learning. There are critical anatomical and functional differences in how SCs and BCs provide feed-forward inhibition of PCs in response to PF and CF activation. SCs primarily transmit chemical inhibition through axo-dendritic synapses whereas BCs deliver both chemical and electrical field inhibition through axo-somatic and axo-axonic synapses, respectively (Palay \& Chan-Palay, 1974b; Korn \& Axelrad, 1980; Blot \& Barbour, 2014). Recent tamoxifen-mediated temporal deletions of the GABAergic transporter have suggested that BCs and SCs may have a distinct function in regulating PC simple spike firing pattern and rate (Brown et al, 2019). Our analysis of Shh signaling mutants provides evidence that SCs contribute significantly to motor learning. We found that the $21 \%$ reduction of SC numbers had a profound consequence on the cerebellar circuitry, resulting in a nearly $31 \%$ reduction in dendritic inhibitory synapses and significant impairment of inhibitory neurotransmission. This impairment in dendritic synapses and GABAergic input onto PCs is sufficient to cause motor learning deficit. It remains to be determined whether axo-somatic and axo-axonic synapses contribute to motor learning.

\section{ACKNOWLEDGEMENTS}

We thank Jingqiong Kang, Ph.D. and Chun-Qing Zhang, M.D. for their initial help with electrophysiology experiments. We thank Christopher Wright, D.Phil. for the generous gift of antibody against Ptfla. This study was supported by grants to C.C. from the Vanderbilt-Ingram Cancer Center Support Grant P30 CA068485 and the National Institutes of Health NS 097898. 


\section{AUTHOR CONTRIBUTIONS}

C.C. designed the experiments and wrote the paper with the help of W.L. and L.C. W.L. performed all the experiments except eyeblink conditioning and ERG. W. L. performed the electrophysiology experiment with the help of K.A.Z. and A.H.L. L.C., W.L. and J.T.F. performed eyeblink conditioning experiment with the help of S.A.H., G.J.W. and J.F.M. The ERG data was provided by T.S.R. C.C., W.L. and L.C. analyzed data.

\section{DECLARATION OF INTERESTS}

The authors declare no competing interests.

KEY RESOURCES TABLE

\begin{tabular}{|c|c|c|c|}
\hline $\begin{array}{c}\text { Reagent or } \\
\text { Resource }\end{array}$ & Source & Identifiers & $\begin{array}{l}\text { Additional } \\
\text { information }\end{array}$ \\
\hline \multicolumn{4}{|l|}{ Antibody } \\
\hline $\begin{array}{l}\text { Rabbit monoclonal } \\
\text { anti - } \beta \text {-Gal }\end{array}$ & $\begin{array}{l}\text { ICL lab } \\
\text { Cat\#RGAL-45A-Z }\end{array}$ & $\begin{array}{l}\text { Cat\#RGAL-45A-Z } \\
\text { RRID: AB_2885032 }\end{array}$ & $1: 4000$ \\
\hline $\begin{array}{l}\text { Goat polyclonal } \\
\text { anti-Ptf1a }\end{array}$ & (Fleming et al, 2013) & NA & $1: 8000$ \\
\hline $\begin{array}{l}\text { Mouse monoclonal } \\
\text { anti - Parvalbumin }\end{array}$ & EnCor Biotechnology & $\begin{array}{l}\text { Cat\# MCA-3C9, } \\
\text { RRID: AB_2572372 }\end{array}$ & $1: 1000$ \\
\hline $\begin{array}{l}\text { Rabbit monoclonal } \\
\text { anti - Calbindin }\end{array}$ & $\begin{array}{l}\text { Cell Signaling } \\
\text { Technology }\end{array}$ & $\begin{array}{l}\text { Cat\# 2173, } \\
\text { RRID:AB_2183553 }\end{array}$ & $1: 500$ \\
\hline $\begin{array}{l}\text { Chicken } \\
\text { monoclonal anti - } \\
\text { GFP }\end{array}$ & Aves Labs & $\begin{array}{l}\text { Cat\# GFP-1020, } \\
\text { RRID:AB_10000240 }\end{array}$ & $1: 1000$ \\
\hline $\begin{array}{l}\text { Rabbit monoclonal } \\
\text { Anti-Ret }\end{array}$ & $\begin{array}{l}\text { Cell Signaling } \\
\text { Technology }\end{array}$ & $\begin{array}{l}\text { Cat\# 14556, } \\
\text { RRID: AB_2798509 }\end{array}$ & $1: 500$ \\
\hline $\begin{array}{l}\text { Rabbit monoclonal } \\
\text { anti - Pax2 }\end{array}$ & $\begin{array}{l}\text { Thermo Fisher } \\
\text { Scientific }\end{array}$ & $\begin{array}{l}\text { Cat\# 71-6000, } \\
\text { RRID:AB_2533990 }\end{array}$ & $1: 500$ \\
\hline $\begin{array}{l}\text { Mouse monoclonal } \\
\text { anti - NeuN }\end{array}$ & Millipore & $\begin{array}{l}\text { Cat\# MAB377, } \\
\text { RRID:AB 2298772 }\end{array}$ & $1: 500$ \\
\hline Cyclin D2 & $\begin{array}{l}\text { Santa Cruz } \\
\text { Biotechnology }\end{array}$ & $\begin{array}{l}\text { Cat\# Sc452 } \\
\text { RRID: AB_627350 }\end{array}$ & $1: 100$ \\
\hline
\end{tabular}




\begin{tabular}{|c|c|c|c|}
\hline $\begin{array}{l}\text { Guinea pig } \\
\text { polyclonal anti - } \\
\text { VGAT }\end{array}$ & Synaptic Systems & $\begin{array}{l}\text { Cat\# } 131004, \\
\text { RRID:AB_887873 }\end{array}$ & $1: 500$ \\
\hline $\begin{array}{l}\text { Mouse monoclonal } \\
\text { anti - Gephyrin }\end{array}$ & Synaptic Systems & $\begin{array}{l}\text { Cat\# } 147011, \\
\text { RRID:AB_887717 }\end{array}$ & $1: 500$ \\
\hline $\begin{array}{l}\text { Mouse monoclonal } \\
\text { anti - vGluT1 }\end{array}$ & Millipore & $\begin{array}{l}\text { Cat\# MAB5502, } \\
\text { RRID:AB_262185 }\end{array}$ & $1: 1000$ \\
\hline $\begin{array}{l}\text { Rabbit polyclonal } \\
\text { anti - vGluT2 }\end{array}$ & Synaptic Systems & $\begin{array}{l}\text { Cat\# } 135403, \\
\text { RRID:AB_887883 }\end{array}$ & $1: 100$ \\
\hline $\begin{array}{l}\text { Mouse monoclonal } \\
\text { anti - Kv1.2 }\end{array}$ & Millipore & $\begin{array}{l}\text { Cat\# MABN77, } \\
\text { RRID:AB_10806493 }\end{array}$ & $1: 1000$ \\
\hline $\begin{array}{l}\text { Rabbit monoclonal } \\
\text { anti - Cleaved } \\
\text { Caspase-3 }\end{array}$ & $\begin{array}{l}\text { Cell Signaling } \\
\text { Technology }\end{array}$ & $\begin{array}{l}\text { Cat\# 9661, } \\
\text { RRID:AB_2341188 }\end{array}$ & $1: 500$ \\
\hline $\begin{array}{l}\text { Mouse monoclonal } \\
\text { anti - Gad67 }\end{array}$ & Synaptic Systems & $\begin{array}{l}\text { Cat\# } 198211, \\
\text { RRID:AB_2721099 }\end{array}$ & $1: 100$ \\
\hline $\begin{array}{l}\text { Goat anti - mouse } \\
\text { Alexa Fluor } 488\end{array}$ & $\begin{array}{l}\text { Thermo Fisher } \\
\text { Scientific }\end{array}$ & $\begin{array}{l}\text { Cat\# A-11017, } \\
\text { RRID:AB_2534084 }\end{array}$ & $1: 500$ \\
\hline $\begin{array}{l}\text { Goat anti - rabbit } \\
\text { Alexa Fluor } 488\end{array}$ & $\begin{array}{l}\text { Thermo Fisher } \\
\text { Scientific }\end{array}$ & $\begin{array}{l}\text { Cat\# A-11008, } \\
\text { RRID:AB_143165 }\end{array}$ & $1: 500$ \\
\hline $\begin{array}{l}\text { Goat anti - mouse } \\
\text { Alexa Fluor } 568\end{array}$ & $\begin{array}{l}\text { Thermo Fisher } \\
\text { Scientific }\end{array}$ & $\begin{array}{l}\text { Cat\# A-11004, } \\
\text { RRID:AB_2534072 }\end{array}$ & $1: 500$ \\
\hline $\begin{array}{l}\text { Goat anti - rabbit } \\
\text { Alexa Fluor } 647\end{array}$ & $\begin{array}{l}\text { Thermo Fisher } \\
\text { Scientific }\end{array}$ & $\begin{array}{l}\text { Cat\# A-21244, } \\
\text { RRID:AB_2535812 }\end{array}$ & $1: 500$ \\
\hline $\begin{array}{l}\text { Goat anti - chicken } \\
\text { Alexa Fluor } 488\end{array}$ & $\begin{array}{l}\text { Thermo Fisher } \\
\text { Scientific }\end{array}$ & $\begin{array}{l}\text { Cat\# A-11039, } \\
\text { RRID:AB_2534096 }\end{array}$ & $1: 500$ \\
\hline $\begin{array}{l}\text { Donkey anti - goat } \\
\text { Alexa Fluor } 647\end{array}$ & $\begin{array}{l}\text { Thermo Fisher } \\
\text { Scientific }\end{array}$ & $\begin{array}{l}\text { Cat\# A-21447, } \\
\text { RRID:AB_2535864 }\end{array}$ & $1: 500$ \\
\hline $\begin{array}{l}\text { Donkey anti - } \\
\text { rabbit Alexa Fluor } \\
488\end{array}$ & $\begin{array}{l}\text { Thermo Fisher } \\
\text { Scientific }\end{array}$ & $\begin{array}{l}\text { Cat\# A-21206, } \\
\text { RRID:AB_2535792 }\end{array}$ & $1: 500$ \\
\hline Reagent & \multicolumn{2}{|c|}{ Source } & Identifier \\
\hline \multicolumn{4}{|c|}{ Chemicals, Peptides, and Recombinant Proteins } \\
\hline DAPI & \multicolumn{2}{|c|}{ Sigma } & D9542 \\
\hline EdU & \multicolumn{2}{|l|}{ Click Chemistry Tools } & $1149-500$ \\
\hline Tamoxifen & \multicolumn{2}{|l|}{ Millipore } & 156738 \\
\hline
\end{tabular}




\begin{tabular}{|c|c|c|}
\hline Corn oil & Sigma & C8267 \\
\hline $\begin{array}{l}\text { KAPA2G Fast } \\
\text { HotStart } \\
\text { Genotyping Mix }\end{array}$ & Millipore & 2GFHSGKB \\
\hline $\mathrm{Nacl}$ & Sigma & S7653 \\
\hline $\mathrm{Kcl}$ & Sigma & P9333 \\
\hline $\mathrm{Mgcl}_{2} \cdot 6 \mathrm{H}_{2} \mathrm{O}$ & Research Products International & 7791-18-6 \\
\hline $\mathrm{KH}_{2} \mathrm{PO}_{4}$ & Sigma & P0662 \\
\hline $\mathrm{NaHCO}_{3}$ & Sigma & S5761 \\
\hline $\mathrm{Cacl}_{2} \cdot 2 \mathrm{H}_{2} \mathrm{O}$ & Sigma & 223506 \\
\hline D-glucose & Sigma & G8270 \\
\hline Cscl & Sigma & 289329 \\
\hline HEPES & Sigma & H3375 \\
\hline EGTA & Research Products International & $67-42-5$ \\
\hline Mg-ATP & R\&D System & B-20 \\
\hline GTP & Sigma & GE27-2076-01 \\
\hline CNQX & Millipore & 3266820 \\
\hline APV & Sigma & A5282 \\
\hline Diphtheria toxin & & \\
\hline Animal models & \multicolumn{2}{|l|}{ Source and Identifier } \\
\hline Gli1 $1^{\text {nlaz }}$ & \multicolumn{2}{|l|}{$\begin{array}{l}\text { The Jackson Laboratory. Stock No.008211. } \\
\text { (Bai et al, 2002) }\end{array}$} \\
\hline Ptf1a $\mathrm{Cre/+}$ & \multicolumn{2}{|l|}{ (Kawaguchi et al, 2002) } \\
\hline $\mathrm{Smo}^{\mathrm{F} / \mathrm{F}}$ & \multicolumn{2}{|l|}{$\begin{array}{l}\text { The Jackson Laboratory. Stock No.008211. } \\
\text { (Long et al, 2001) }\end{array}$} \\
\hline SmoM2 & \multicolumn{2}{|l|}{$\begin{array}{l}\text { The Jackson Laboratory. Stock No.005130. } \\
\text { (Jeong et al, 2004) }\end{array}$} \\
\hline Ret GFP/+ & \multicolumn{2}{|l|}{$\begin{array}{l}\text { The Jackson Laboratory. Stock No. } 029846 . \\
\text { (Jain et al, 2006) }\end{array}$} \\
\hline Ptf1a $\mathrm{a}^{\mathrm{CreER} /+}$ & \multicolumn{2}{|l|}{$\begin{array}{l}\text { The Jackson Laboratory. Stock No.019378. } \\
\text { (Kopinke et al, 2012) }\end{array}$} \\
\hline Ai9 & \multicolumn{2}{|l|}{$\begin{array}{l}\text { The Jackson Laboratory. Stock No.007905. } \\
\text { (Madisen et al, 2010) }\end{array}$} \\
\hline iDTR & \multicolumn{2}{|l|}{$\begin{array}{l}\text { The Jackson Laboratory. Stock No.007900. } \\
\text { (Buch et al, 2005) }\end{array}$} \\
\hline
\end{tabular}

\section{EXPERIMENTAL PROCEDURES}

Mice

All procedures followed animal care and biosafety protocols approved by Vanderbilt University Division of Animal Care in accordance with NIH guidelines. Histological analyses were carried out at postnatal (P) 1 to P30. Behavior experiments used 3 to 5 months adult mice. The following 
mouse lines were used in this study:

1. Gli1 $1^{\text {nlaz }}$, nlacZ reporter was inserted into the endogenous Gli1 locus, creating a null allele and activating nlacZ expression in a pattern indistinguishable from that of Gli1 (Bai et al, 2002). 2. Ptfla ${ }^{\mathrm{Cre} /+}$, Cre was inserted into the endogenous Ptfla locus, creating a null allele and activating Cre expression in a pattern indistinguishable from that of Ptfla (Kawaguchi et al, 2002). 3. Ptfla $\mathrm{CreER/+}^{\mathrm{H}}$, CreER was inserted into the endogenous Ptfla locus, creating a null allele and activating CreER expression in a pattern indistinguishable from that of Ptfla (Kopinke et al, 2012). 4. $S m o^{F / F}$, the loxP sequence was inserted on either side of exon 1 at the Smo locus, permitting a Cre recombinase dependent Smo loss of function mice (Long et al, 2001). 5. $R 26^{\text {SmoM2 }}$, a lox-stop-lox eYFP SmoM2 cassette was inserted into ROSA26 locus, permitting the expression of eYFPSmoM2 fusion protein in a Cre dependent manner (Jeong et al, 2004). 6. Ret $^{\text {GFP/+ }}$, exon 1 of the Ret locus was replaced by eGFP, creating a null allele and activating eGFP expression in a pattern similar to that of Ret (Jain et al, 2006). 7. R2 $6^{i D T R}$, a loxp cassette containing diphtheria toxin receptor (DTR) was inserted into ROSA26 locus, permitting the expression of DTR in a Cre dependent manner (Buch et al, 2005). 8. R26R ${ }^{A i 9}$, a CAG lox-stoplox tdtomato cassette was inserted into ROSA26 locus, permitting the expression of tdtomato under the control of CAG promoter in a Cre-dependent manner (Madisen et al, 2010).

\section{Mice treatments}

For proliferation analysis, P3 and P6 pups were injected intraperitoneally with $50 \mathrm{mg} / \mathrm{kg}$ of EdU (5-ethyl-2-deoxyuridine; Sigma). Brains were harvested $2 \mathrm{~h}$ after injection and processed for frozen tissue sections. Fate mapping studies, P0, P3 and P5 pups were injected intraperitoneally with 50 $\mathrm{mg} / \mathrm{kg}$ of EdU (P5 pups only) or $50 \mathrm{mg} / \mathrm{kg}$ of tamoxifen (Sigma) dissolved in corn oil. Brains were 
harvested at P21 and processed for frozen tissue sections as described below. P0 Pups were injected intraperitoneally with 3ng of Diptheria toxin daily for two or three consecutive days for cell ablation experiments. Brains were harvested at P6 or P21 for frozen tissue sections.

\section{Tissue processing for histological analysis}

Brains were retrieved from P0 to P8 after cervical dislocation and from deeply anesthetized adults after transcardial perfusion with $4 \%$ paraformaldehyde (PFA). Animals were anesthetized with $100 \mathrm{mg} / \mathrm{kg}$ ketamine and $5 \mathrm{mg} / \mathrm{kg}$ of Xylazine. Brains were then fixed with $4 \%$ PFA for 48 hours at $4^{\circ} \mathrm{C}$ and processed for paraffin embedding. Sections of $5 \mathrm{~mm}$ were then collected on glass slides (Fisher) and paraffin was removed using xylene in a 3-wash series ( 1 x 10 minutes, 2 x 5 minutes). Sections were rehydrated with a descending EtOH series (100\% (2x), 95\%, 75\%, 50\%) 3 minutes each followed by two 1-minute washes in $\mathrm{H}_{2} \mathrm{O}$. Sections were stained with hematoxylin and eosin solution. Golgi stains on adult sections were performed using FD Rapid GolgiStain Kit (FD NeuroTechnologies, Inc) according to manufactural instruction.

\section{Immunohistochemistry}

Immunohistochemistry analyses were performed on frozen tissue sections. Fixed brain tissues described above were rinsed with PBS and immersed in $30 \%$ sucrose solution before embedding in tissue freezing medium (OCT). Frozen tissues were sectioned on the Leica CM1950 cryostat at $15 \mathrm{~mm}$. Endogenous peroxidases were blocked with $3 \% \mathrm{H}_{2} \mathrm{O}_{2}$ in $\mathrm{MeOH}\left(5 \mathrm{~mL} 30 \% \mathrm{H}_{2} \mathrm{O}_{2}\right.$ in 45 $\mathrm{mL} 100 \% \mathrm{MeOH}$ for 10 minutes followed with a 1x PBS wash for 3 x 5 minutes. Sections were incubated with PBS blocking solution containing 10\% normal goat or donkey serum and $0.1 \%$ Triton X-100 at room temperature for 1 hour. A moisture chamber was prepared and slides placed 
into it. $100 \mu \mathrm{L}$ of primary antibody (prepared in PBS blocking solution) per slide was added and each was covered with a coverslip and allowed to sit overnight at $4^{\circ} \mathrm{C}$. The following day, coverslips were removed and slides were washed in 1x PBS, 3 x 5 minutes each. $100 \mu \mathrm{L}$ of secondary antibody per slide was added and each was covered with a coverslip and allowed to sit for 1 hour at room temperature. Slides were washed in 1x PBS, 3 x 5 minutes each and were mounted using Fluorosave (Millipore) before imaging. For EdU detection, sections were incubated in PBS with 0.1M CuSO4, 0.1M THPTA, 2mM Azide 488, 1M L- Ascorbic at room temperature for 30min. Sections were washed 3x5minutes in PBS and then incubated with $5 \mu \mathrm{g} / \mathrm{ml}$ DAPI at room temperature for 10 minutes. All fluorescent images were acquired on Leica DMi8 microscope or Zeiss LSM 700 confocal microscope, processed using Leica LAS X or Zeiss Zen software and analyzed using NIH ImageJ.

\section{Rotarod test}

Motor coordination and learning were tested using a commercially available (Harvard Apparaus) accelerating rotarod. The cylinder was $3 \mathrm{~cm}$ in diameter and was covered with textured rubber. Mice were confined to a section of the cylinder $5.7 \mathrm{~cm}$ wide by grey plastic dividers. The height to fall was $16 \mathrm{~cm}$. Mice were placed on the accelerating rotarod whose speed gradually increased from 4 to $40 \mathrm{rpm}$ over the course of a $300 \mathrm{~s}$ trial. The time taken for the mouse to fall from the rotating rod was recorded. Mice that fell in less than $15 \mathrm{~s}$ were given a second trial. Occasionally, mice clung to the rod, and the whole animal rotated along with it. This behavior was classified as a "rotation," and the time at which this occurred for the first time on each trial was also recorded for each mouse. Thus the rotarod score was defined as latency to fall or to the first rotation, 
whichever occurred first. Three sessions were conducted on consecutive days, with three trials per session.

\section{Gait analysis}

Mice were placed on a translucent treadmill at a standstill. The treadmill was then turned on at a speed of $20 \mathrm{~cm} / \mathrm{s}$, and still images of their paw movements and placements were taken with a highspeed video camera underneath the belt. Only 10-20 seconds of footage was recorded to obtain $\sim 40$ indices of gait from the analysis software. The following parameters were measured: stance time, time elapsed while foot is in contact with the treadmill, in its stance phase; swing time, time elapsed while foot is in the air, in its swing phase; stride time, time elapsed between two successive initiations of stances; brake time, time elapsed from the first contact with the treadmill to peak of stance; deceleration; propel time, time elapsed from peak stance to full swing.

\section{Eyeblink conditioning in head-fixed mice}

The apparatus and experimental procedure for eyeblink conditioning were previously described (Heiney et al, 2014). Briefly, mice were anesthetized with isoflurane (1.5-2\% by volume) and positioned on the stereotaxic apparatus prepared for surgery. The skull was exposed, and two small holes were drilled on either side of the midline near bregma for inserting screws. A thin aluminum head plate was then placed over the bregma and the screws were fitted into the central hole in the head plate, which was affixed to the skull by Metabond cement.

Mice were habituated to head restraint for an hour in 3 habituation sesseions on top of a foam cylinder with the head fixed before start of the conditioning sessions. Mice were exposed to either a $240 \mathrm{~ms}$ blue LED light positioned $20 \mathrm{~cm}$ in front of the mouse or a $240 \mathrm{~ms}$ tone of white 
noise delivered via a speaker (4- $\Omega$ magnetic speaker, FF1, TDT) as a conditioned stimulus (CS). The volume of the white noise was set to just below the threshold that causes transient startle movement of the eyelid. The unconditioned stimulus (US) was a periocular air puff (30 - 40 psi) of $40 \mathrm{~ms}$ duration and delivered via a 23 gauge needle placed $5 \mathrm{~mm}$ from the mouse's cornea. The pressure of the periocular air puff was set for each mouse to induce a full reflexive blink as the unconditional response (UR). The CS-US inter-stimulus interval was 200 ms. Mice received 100 trials (80 CS-US paired trials and 20 CS-only trials) per day for 14 days. Eyelid movement was detected under infrared illumination using a high-speed (200 or 350 frames/s) monochrome video camera (Allied Vision). Eyelid positions, ranging from 1 (fully closed) to 0 (fully opened), were determined as the fraction of eyelid closure (FEC) using custom MATLAB software and the Video Acquisition Toolbox. The FEC represents the proportion of the distance between the two eyelids. The response was considered to be a conditioned response (CR) if the FEC exceeded 0.2 after the CS onset but before the US.

\section{Electrophysiology recording}

Cerebella from P21 to P30 were retrieved and embedded in agarose while affixed to the specimen holder using adhesive glue. $300 \mathrm{~mm}$ thick sagittal slices of cerebellar vermis were prepared using a vibrating microtome (VT1000S, Leica) in oxygenated prechilled medium containing $125 \mathrm{mM}$ $\mathrm{NaCl}, 2.5 \mathrm{mM} \mathrm{KCl}, 4 \mathrm{mM} \mathrm{MgCl} 2,1.25 \mathrm{mM}$ KH2PO4, 26 mM NaHCO3, $1 \mathrm{~m} \mathrm{CaCl}$, and $25 \mathrm{mM}$ D-glucose ( $\mathrm{pH}$ 7.3-7.4). The slices were then transferred to a recording chamber and superfused with artificial cerebrospinal fluid (aCSF) and gassed with a mixture of $95 \% \mathrm{O}_{2} / 5 \% \mathrm{CO}_{2}>1$ hour at ice-cold temperature before recordings. Whole-cell recordings from Purkinje cells in cerebellar lobules 4-7 (voltage-clamped at $-60 \mathrm{mV}$ ) were performed at room temperature with borosilicate 
glass pipettes (2-4 M 2 ) pulled with a vertical micropipette puller (PC-10, Narishige). Recording electrodes were filled with internal solution containing $140 \mathrm{mM} \mathrm{CsCl}, 4 \mathrm{mM} \mathrm{NaCl}, 0.5 \mathrm{mM} \mathrm{CaCl}$, 10 mM HEPES, 5 mM EGTA, 2 mM Mg-ATP and 0.4 mM GTP (pH 7.3). For sIPSCs recording, $10 \mathrm{mM}$ 6-Cyano-7-nitroquinoxaline-2,3-dione (CNQX) and 50 to $100 \mathrm{mM}$ amino-5 phosphonopentanoic acid (APV) were added to the external solution to block glutamate receptormediated sEPSCs. Membrane currents were recorded using a Multiclamp 700B amplifier (Axon Instruments) connected to a DigiData 1440 (Molecular Devices) using pClamp 10.2 software (Molecular Devices). Series resistance (8-14 M $\Omega$ ) was monitored throughout the experiments, and experimental data were discarded if the value changed by $>20 \%$. All signals were filtered at $2 \mathrm{kHz}$ and sampled at 5-10 kHz. sIPSCs were analyzed with a threshold of $10 \mathrm{pA}$. Postsynaptic currents were analyzed using Clampfit 11 software (Molecular Devices). Amplitudes and inter-eventinterval were measured as a mean of the values obtained from $5 \mathrm{~min}$ recording sessions and analyzed using Prism software 8 (GraphPad) for statistical analysis and graphic presentations.

\section{ERG and VEP Recordings}

Mice were dark-adapted overnight, dilated with $1 \%$ tropicamide for $10 \mathrm{~min}$, and anesthetized with 20/8/0.8 mg/kg ketamine/xylazine/urethane. Anesthetized mice were placed on the warmed surface of the Celeris ERG system (Diagnosys LLC, Lowell, MA) and corneal electrodes were placed on eyes lubricated with Genteel eye drops. Subdermal platinum needle electrodes were placed in the snout and tail as reference and ground electrodes, respectively. Additional platinum electrodes were placed on the right and left sides of the back of the head, near the visual cortex. The ERG and VEP were recorded sequentially during the same session. For the ERG recording, mice were exposed to 15 flashes of $1 \mathrm{~Hz}, 1 \mathrm{~cd} . \mathrm{s} / \mathrm{m}^{2}$ white light. For the VEP recording, mice were 
exposed to 50 flashes of $1 \mathrm{~Hz}, 0.5 \mathrm{~cd} . \mathrm{s} / \mathrm{m}^{2}$ white light. At the end of the session, mice recovered on a warm pad and then were returned to their cage.

\section{Quantifications and Statistical Analysis}

NIH Image $\mathbf{J}$ software was used to measure the area $\left(\mu \mathrm{m}^{2}\right)$ for regions of interest (ROI) and for the acquisition of cell counting. For each stage, four to six midsagittal sections (approximately 10 um thick) of each cerebellum were used for quantitative analysis. For quantification of cells in the white matter, inner granule layer and molecular layer, the entire laminate was used as ROIs. Cells were counted using Image $\mathrm{J}$ plugin Cell counter or Nucleus counter according to the subcellular distribution of target antigen. For quantification of synapses, four to five $5000 \mu \mathrm{m}^{2}$ rectangular ROIs in the molecular layer of lobule IV and V per sample were used. Positively stained puncta were counted by Image $\mathbf{J}$ plugin PunctaAnalyzer. For quantification of PC spine density, DIC images were taken on a Leica TCS SP5 microscope of sagittal cerebellar sections from Ptfla ${ }^{\text {Cre }}$; $S m o^{F /-}$ mice and control littermates. Images were taken at a picture size of 1024x1024 pixels, and a 63x objective was used for dendritic spine counting analysis. Z-stacks of individual cells were captured and the length of dendritic spines was measured by tracing a segmented line from the base of the spine to its apex. The number of spines per visible segment was quantified manually in Image $\mathbf{J}$ and provided an index of spine density (spines per $\mu \mathrm{m}$ ). Manual-counting was done blindly and only spines that had strong, clear Golgi stain were counted. All quantitative data were analyzed using Prism software 8 (GraphPad) for statistical analysis and graphic presentations. Unpaired student's t-test was used to compare the statistical difference between control and conditional mutant animals. 


\section{REFERENCES}

Altman J \& Bayer SA (1997) Development of the Cerebellar System in relation to its evolution, structure, and function.

Asada H, Kawamura Y, Maruyama K, Kume H, Ding R, Ji FY, Kanbara N, Kuzume H, Sanbo M, Yagi T, et al (1996) Mice Lacking the $65 \mathrm{kDa}$ Isoform of Glutamic Acid Decarboxylase (GAD65) Maintain Normal Levels of GAD67 and GABA in Their Brains but Are Susceptible to Seizures. Biochem Bioph Res Co 229: 891-895

Bai CB, Auerbach W, Lee JS, Stephen D \& Joyner AL (2002) Gli2, but not Gli1, is required for initial Shh signaling and ectopic activation of the Shh pathway. Development (Cambridge, England) 129: 4753-4761

Bai CB, Stephen D \& Joyner AL (2004) All mouse ventral spinal cord patterning by hedgehog is Gli dependent and involves an activator function of Gli3. Developmental cell 6: 103-115

Beckinghausen J \& Sillitoe RV (2018) Insights into cerebellar development and connectivity. Neurosci Lett 688: 2-13

Blot A \& Barbour B (2014) Ultra-rapid axon-axon ephaptic inhibition of cerebellar Purkinje cells by the pinceau. Nat Neurosci 17: 289-295

Brinke MM ten, Boele H-J, Spanke JK, Potters J-W, Kornysheva K, Wulff P, IJpelaar ACHG, Koekkoek SKE \& Zeeuw CID (2015) Evolving Models of Pavlovian Conditioning: Cerebellar Cortical Dynamics in Awake Behaving Mice. Cell reports 13: 1977-1988

Brown AM, Arancillo M, Lin T, Catt DR, Zhou J, Lackey EP, Stay TL, Zuo Z, White JJ \& Sillitoe RV (2019) Molecular layer interneurons shape the spike activity of cerebellar Purkinje cells. Nature Publishing Group: 1-19

Buch T, Heppner FL, Tertilt C, Heinen TJAJ, Kremer M, Wunderlich FT, Jung S \& Waisman A (2005) A Cre-inducible diphtheria toxin receptor mediates cell lineage ablation after toxin administration. Nat Methods 2: 419-426

Cadilhac C, Bachy I, Forget A, Hodson DJ, Jahannault-Talignani C, Furley AJ, Ayrault O, Mollard P, Sotelo C \& Ango F (2021) Excitatory granule neuron precursors orchestrate laminar localization and differentiation of cerebellar inhibitory interneuron subtypes. Cell Reports 34: 108904

Cameron DB, Kasai K, Jiang Y, Hu T, Saeki Y \& Komuro H (2009) Four distinct phases of basket/stellate cell migration after entering their final destination (the molecular layer) in the developing cerebellum. Dev Biol 332: 309-324 
Costantini F (2016) Kidney Development, Disease, Repair and Regeneration. Sect Dev: 41-56

Dahmane N \& Altaba AR i (1999) Sonic hedgehog regulates the growth and patterning of the cerebellum. Development (Cambridge, England) 126: 3089-100.

Fleming JT, He W, Hao C, Ketova T, Pan FC, Wright CCV, Litingtung Y \& Chiang C (2013) The Purkinje neuron acts as a central regulator of spatially and functionally distinct cerebellar precursors. Developmental cell 27: 278-292

Fujitani Y, Fujitani S, Luo H, Qiu F, Burlison J, Long Q, Kawaguchi Y, Edlund H, MacDonald RJ, Furukawa T, et al (2006) Ptfla determines horizontal and amacrine cell fates during mouse retinal development. Development 133: 4439-4450

Glasgow SM, Henke RM, Macdonald RJ, Wright CV \& Johnson JE (2005) Ptfla determines GABAergic over glutamatergic neuronal cell fate in the spinal cord dorsal horn. Development (Cambridge, England) 132: 5461-5469

Heiney SA, Wohl MP, Chettih SN, Ruffolo LI \& Medina JF (2014) Cerebellar-Dependent Expression of Motor Learning during Eyeblink Conditioning in Head-Fixed Mice. Journal of Neuroscience 34: 14845-14853

Hoshino M, Nakamura S, Mori K, Kawauchi T, Terao M, Nishimura YV, Fukuda A, Fuse T, Matsuo N, Sone M, et al (2005) Ptfla, a bHLH transcriptional gene, defines GABAergic neuronal fates in cerebellum. Neuron 47: 201-213

Huang X, Ketova T, Fleming JT, Wang H, Dey SK, Litingtung Y \& Chiang C (2009) Sonic hedgehog signaling regulates a novel epithelial progenitor domain of the hindbrain choroid plexus. Development (Cambridge, England) 136: 2535-2543

Huard JM, Forster CC, Carter ML, Sicinski P \& Ross ME (1999) Cerebellar histogenesis is disturbed in mice lacking cyclin D2. Dev Camb Engl 126: 1927-35

Jain S, Golden JP, Wozniak D, Pehek E, Johnson EM \& Milbrandt J (2006) RET Is Dispensable for Maintenance of Midbrain Dopaminergic Neurons in Adult Mice. J Neurosci 26: 1123011238

Jeong J, Mao J, Tenzen T, Kottmann AH \& McMahon AP (2004) Hedgehog signaling in the neural crest cells regulates the patterning and growth of facial primordia. Genes \& development 18: 937-951

Kash SF, Johnson RS, Tecott LH, Noebels JL, Mayfield RD, Hanahan D \& Baekkeskov S (1997) Epilepsy in mice deficient in the $65-\mathrm{kDa}$ isoform of glutamic acid decarboxylase. Proc National Acad Sci 94: 14060-14065 
Kawaguchi Y, Cooper B, Gannon M, Ray M, MacDonald RJ \& Wright CVE (2002) The role of the transcriptional regulator Ptfla in converting intestinal to pancreatic progenitors. Nat Genet 32: $128-134$

Kopinke D, Brailsford M, Pan FC, Magnuson MA, Wright CVE \& Murtaugh LC (2012) Ongoing Notch signaling maintains phenotypic fidelity in the adult exocrine pancreas. Dev Biol 362: 57-64

Korn H \& Axelrad H (1980) Electrical inhibition of Purkinje cells in the cerebellum of the rat. Proc National Acad Sci 77: 6244-6247

Lake JI \& Heuckeroth RO (2013) Enteric nervous system development: migration, differentiation, and disease. Am J Physiol-gastr L 305: G1-G24

Leto K, Bartolini A, Yanagawa Y, Obata K, Magrassi L, Schilling K \& Rossi F (2009) Laminar Fate and Phenotype Specification of Cerebellar GABAergic Interneurons. Journal of Neuroscience 29: 7079-7091

Leto K, Carletti B, Williams IM, Magrassi L \& Rossi F (2006) Different Types of Cerebellar GABAergic Interneurons Originate from a Common Pool of Multipotent Progenitor Cells. $J$ Neurosci 26: 11682-11694

Long F, Zhang XM, Karp S, Yang Y \& McMahon AP (2001) Genetic manipulation of hedgehog signaling in the endochondral skeleton reveals a direct role in the regulation of chondrocyte proliferation. Dev Camb Engl 128: 5099-108

Machold R \& Fishell G (2005) Math1 is expressed in temporally discrete pools of cerebellar rhombic-lip neural progenitors. Neuron 48: 17-24

Madisen L, Zwingman TA, Sunkin SM, Oh SW, Zariwala HA, Gu H, Ng LL, Palmiter RD, Hawrylycz MJ, Jones AR, et al (2010) A robust and high-throughput Cre reporting and characterization system for the whole mouse brain. Nat Neurosci 13: 133-140

Mao J, Ligon KL, Rakhlin EY, Thayer SP, Bronson RT, Rowitch D \& McMahon AP (2006) A novel somatic mouse model to survey tumorigenic potential applied to the Hedgehog pathway. Cancer Res 66: 10171-10178

Medina JF, Nores WL, Ohyama T \& Mauk MD (2000) Mechanisms of cerebellar learning suggested by eyelid conditioning. Curr Opin Neurobiol 10: 717-724

Mendelsohn C, Batourina E, Fung S, Gilbert T \& Dodd J (1999) Stromal cells mediate retinoiddependent functions essential for renal development. Dev Camb Engl 126: 1139-48

Orchard P, White JS, Thomas PE, Mychalowych A, Kiseleva A, Hensley J, Allen B, Parker SCJ \& Keegan CE (2018) Genome-wide chromatin accessibility and transcriptome profiling show 
minimal epigenome changes and coordinated transcriptional dysregulation of hedgehog signaling in Danforth's short tail mice. Hum Mol Genet 28: 736-750

Palay SL \& Chan-Palay V (1974a) Cerebellar Cortex, Cytology and Organization. 242-287

Palay SL \& Chan-Palay V (1974b) Cerebellar Cortex-Cytology and Organization.

Parmigiani E, Leto K, Rolando C, Figueres-Oñate M, López-Mascaraque L, Buffo A \& Rossi F (2015) Heterogeneity and Bipotency of Astroglial-Like Cerebellar Progenitors along the Interneuron and Glial Lineages. J Neurosci 35: 7388-7402

Pascual M, Abasolo I, Meur AM-L, Martinez A, Rio JAD, Wright CV, Real FX \& Soriano E (2007) Cerebellar GABAergic progenitors adopt an external granule cell-like phenotype in the absence of Ptfla transcription factor expression. Proceedings of the National Academy of Sciences of the United States of America 104: 5193-5198

Pieper A, Rudolph S, Wieser GL, Götze T, Mießner H, Yonemasu T, Yan K, Tzvetanova I, Castillo BD, Bode U, et al (2019) NeuroD2 controls inhibitory circuit formation in the molecular layer of the cerebellum. Sci Rep-uk 9: 1448

Raymond JL \& Medina JF (2018) Computational Principles of Supervised Learning in the Cerebellum. Annu Rev Neurosci 41: 233-253

Sears LL, Finn PR \& Steinmetz JE (1994) Abnormal classical eye-blink conditioning in autism. J Autism Dev Disord 24: 737-751

Sergaki MC, López-Ramos JC, Stagkourakis S, Gruart A, Broberger C, Delgado-García JM \& Ibáñez CF (2017) Compromised Survival of Cerebellar Molecular Layer Interneurons Lacking GDNF Receptors GFR\&alpha;1 or RET Impairs Normal Cerebellar Motor Learning. Cell reports 19: 1977-1986

Silbereis J, Cheng E, Ganat YM, Ment LR \& Vaccarino FM (2009) Precursors with Glial Fibrillary Acidic Protein Promoter Activity Transiently Generate GABA Interneurons in the Postnatal Cerebellum. Stem Cells 27: 1152-1163

Simkin JE, Zhang D, Rollo BN \& Newgreen DF (2013) Retinoic Acid Upregulates Ret and Induces Chain Migration and Population Expansion in Vagal Neural Crest Cells to Colonise the Embryonic Gut. Plos One 8: e64077

Somogyu P \& Hámori J (1976) A quantitative electron microscopic study of the purkinje cell axon initial segment. Neuroscience 1: 361-IN3

Sotelo C (2015) Molecular Layer Interneurons of the Cerebellum: Developmental and Morphological Aspects. The Cerebellum 14: 534-556 
Sudarov A, Turnbull RK, Kim EJ, Lebel-Potter M, Guillemot F \& Joyner AL (2011) Ascl1 genetics reveals insights into cerebellum local circuit assembly. J Neurosci 31: 11055-11069

Wallace VA (1999) Purkinje-cell-derived Sonic hedgehog regulates granule neuron precursor cell proliferation in the developing mouse cerebellum. Curr Biol 9: 445-8.

Wamsley B \& Fishell G (2017) Genetic and activity-dependent mechanisms underlying interneuron diversity. Nat Rev Neurosci 18: 299-309

Wang VY, Rose MF \& Zoghbi HY (2005) Math1 expression redefines the rhombic lip derivatives and reveals novel lineages within the brainstem and cerebellum. Neuron 48: $31-$ 43

Wechsler-Reya RJ \& Scott MP (1999) Control of neuronal precursor proliferation in the cerebellum by Sonic Hedgehog. Neuron 22: 103-14.

Wefers AK, Haberlandt C, Surchev L, Steinhäuser C, Jabs R \& Schilling K (2018) Migration of Interneuron Precursors in the Nascent Cerebellar Cortex. Cerebellum 17: 62-71

Weisheit G, Gliem M, Endl E, Pfeffer PL, Busslinger M \& Schilling K (2006) Postnatal development of the murine cerebellar cortex: formation and early dispersal of basket, stellate and Golgi neurons. Eur J Neurosci 24: 466-478

Wulff P, Schonewille M, Renzi M, Viltono L, Sassoè-Pognetto M, Badura A, Gao Z, Hoebeek FE, Dorp S van, Wisden W, et al (2009) Synaptic inhibition of Purkinje cells mediates consolidation of vestibulo-cerebellar motor learning. Nat Neurosci 12: 1042-1049

Yamanaka H, Yanagawa Y \& Obata K (2004) Development of stellate and basket cells and their apoptosis in mouse cerebellar cortex. Neurosci Res 50: 13-22

Zhang L \& Goldman JE (1996) Generation of cerebellar interneurons from dividing progenitors in white matter. Neuron 16: 47-54

Zhou J, Brown AM, Lackey EP, Arancillo M, Lin T \& Sillitoe RV (2020) Purkinje cell neurotransmission patterns cerebellar basket cells into zonal modules defined by distinct pinceau sizes. Elife 9: e55569 
A

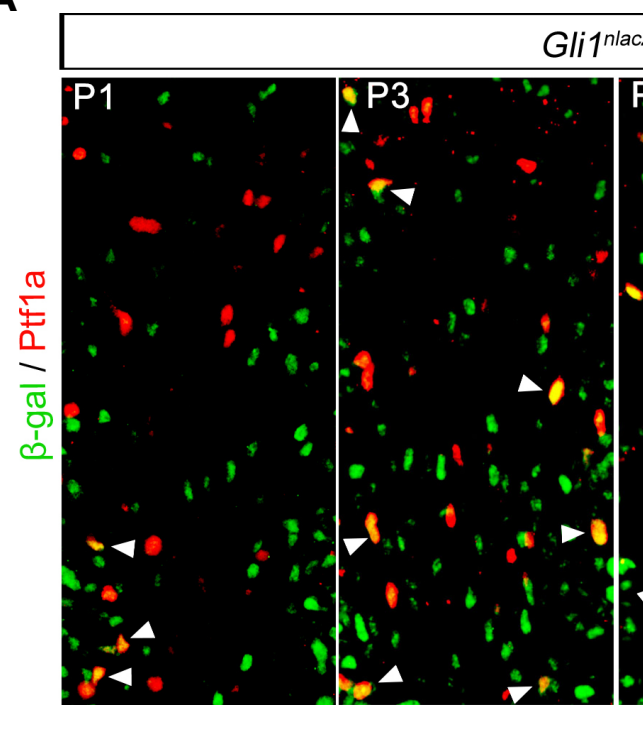

B
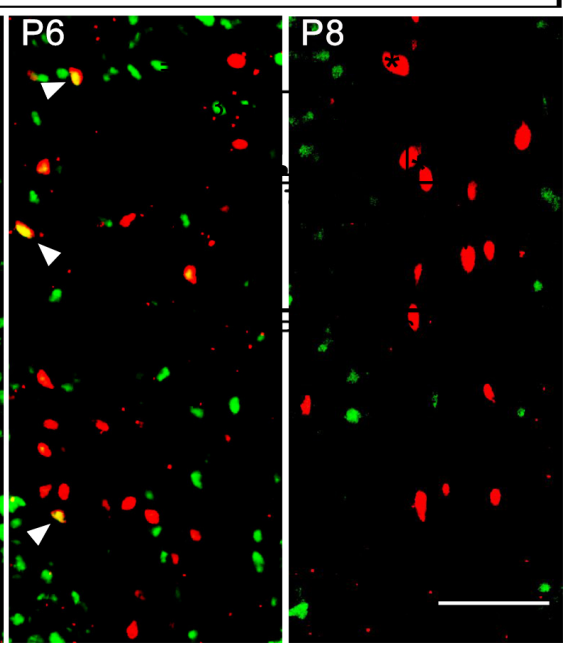

C
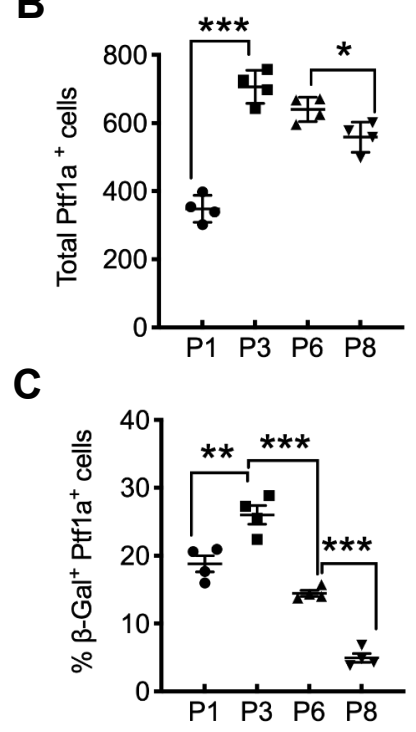

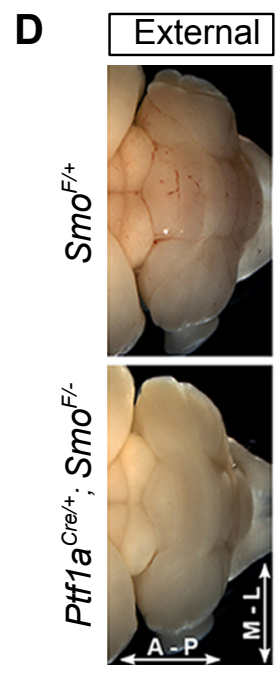

E
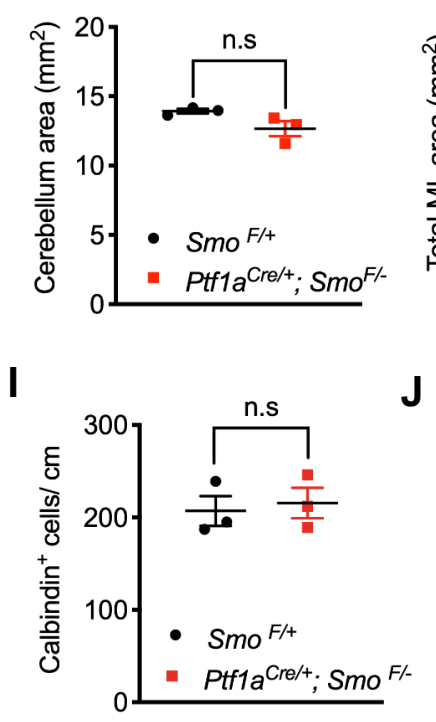

$\mathbf{F}$

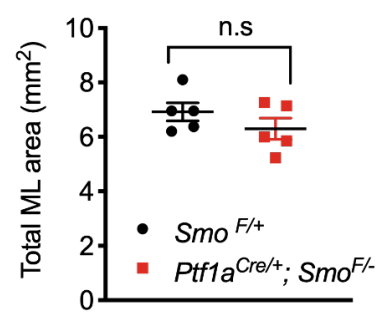

G

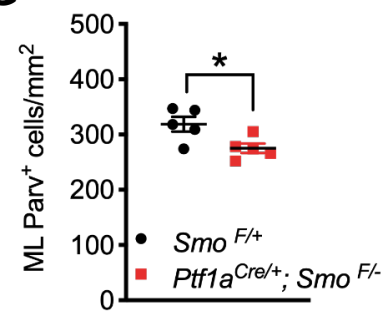

K
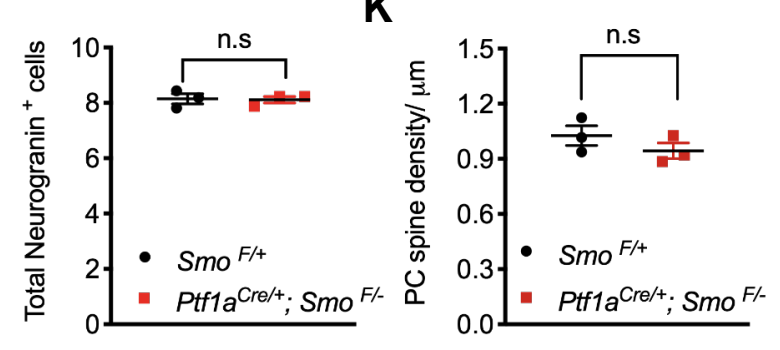
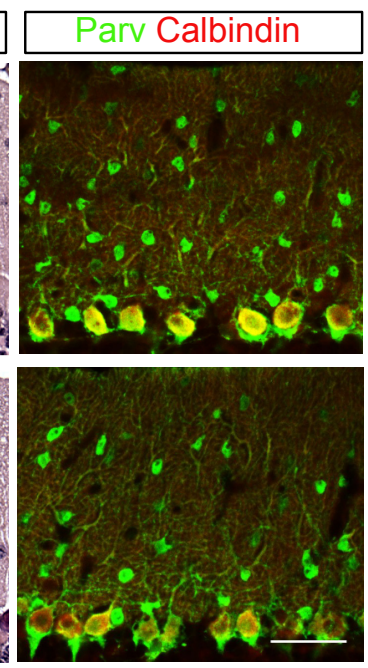

H

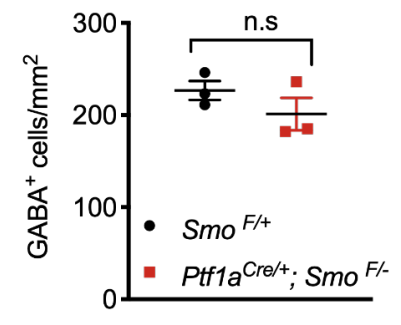

Figure 1, Li et al. 
Figure 1. Shh signaling is transiently activated in Ptf1a+ progenitors and is required for MLI expansion.

(A) Midsagittal sections of Gli $1^{\text {nlacZ }}$ mice showing $\beta$-gal and Ptf1a expression in PWM at P1, P3, P6 and P8. Arrowheads indicate cells co-express $\beta$-gal and Ptfla. Scale bars indicate $50 \mu \mathrm{m}$. (B and C) Quantification of total Ptfla ${ }^{+}$cells (B) and the percentage of $\beta$-gal ${ }^{+} / \mathrm{Ptfla}^{+}$doublepositive cells (C) in the PWM. N= 4 mice per group.

(D) Brains from Smo ${ }^{F /+}$ and Ptfla ${ }^{C r e /+}$ Smo ${ }^{F /-}$ animals at P21 showing external views and H\&E stained sections.

(E and F) Quantification of the overall midsagittal area of the cerebellum and the molecular layer

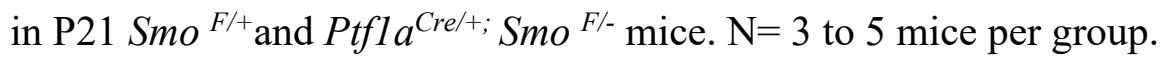

(G) Midsagittal cerebellar sections from P21 Smo ${ }^{\mathrm{F} /+}$ and $\mathrm{Ptfla}^{\mathrm{Cre} /+;} \mathrm{Smo}^{\mathrm{F} /-}$ mice stained with antibodies against parvalbumin (Parv). Scale bars indicate $50 \mu \mathrm{m}$.

(H-J) Quantitative analysis of GABA ${ }^{+}$DCN (H), Parv ${ }^{+}$interneurons (I), Calbindin+ Purkinje cells (I) and Neurogranin+ Golgi cells (J) in P21 Smo ${ }^{\mathrm{F} / \mathrm{+}}$ and Ptfla ${ }^{\mathrm{Cre} / \mathrm{+}}$; Smo ${ }^{\mathrm{F} / \mathrm{-}}$ cerebella. N= 3 to 5 mice per group.

(K) The length of Purkinje cells' dendritic spines in P21 Smo ${ }^{\mathrm{F} /+}$ and $\mathrm{Ptfla}^{\mathrm{Cre} /+;} \mathrm{Smo}^{\mathrm{F} / \mathrm{-}}$ cerebella. $\mathrm{N}=3$ mice per group.

All graphs displayed are mean \pm SEM. ${ }^{*} \mathrm{p} \leq 0.05,{ }^{* *} \mathrm{p} \leq 0.01, * * * \mathrm{p} \leq 0.001$. n.s., not significant. 
bioRxiv preprint doi: https://doi.org/10.1101/2021.04.15.439999; this version posted October 14, 2021. The copyright holder for this preprint (which was not certified by peer review) is the author/funder. All rights reserved. No reuse allowed without permission.

A

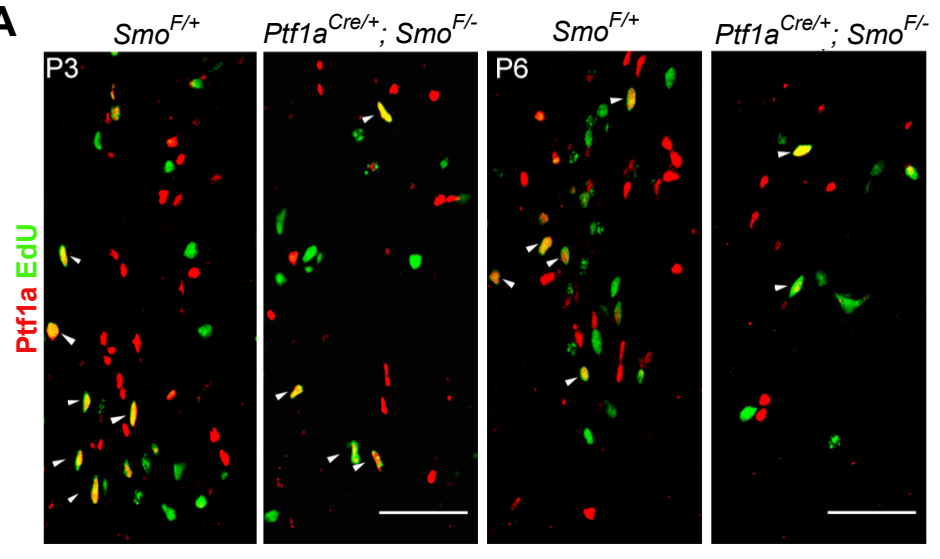

D

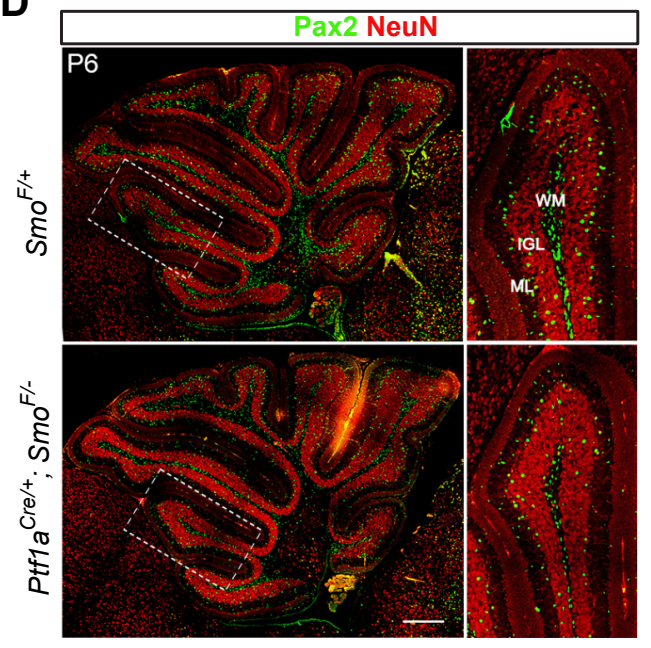

E

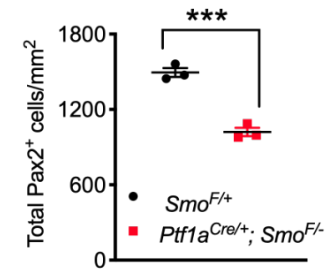

G

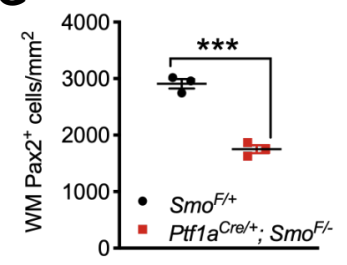

B

C
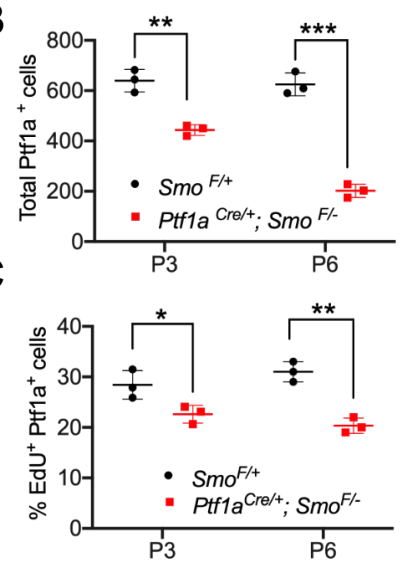

F

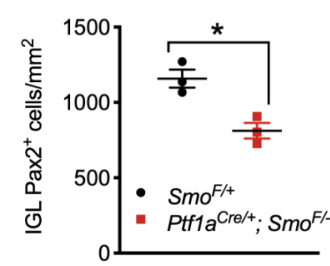

H

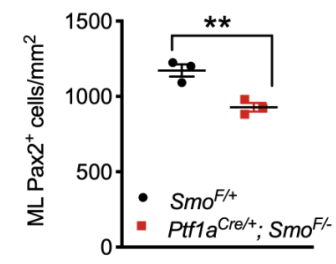

I

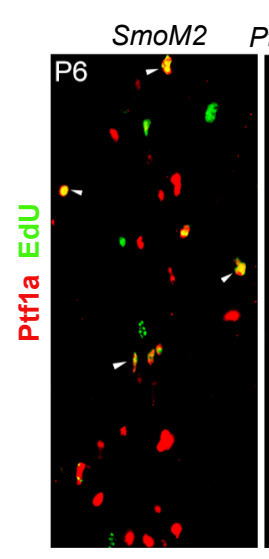

N

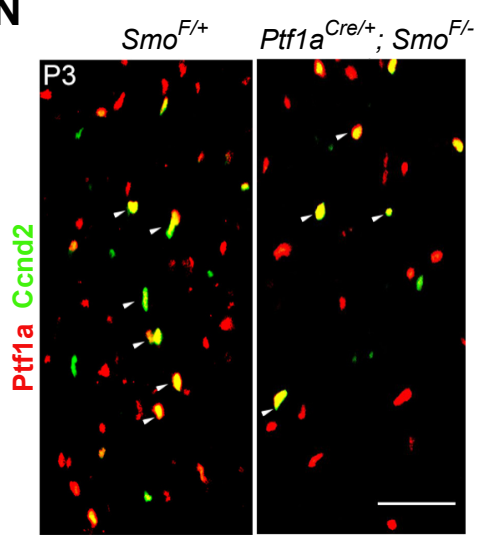

J

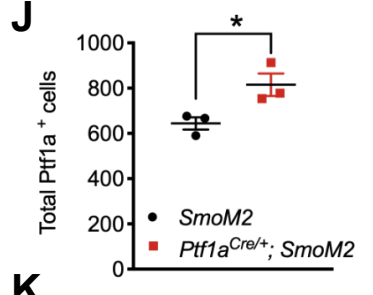

K

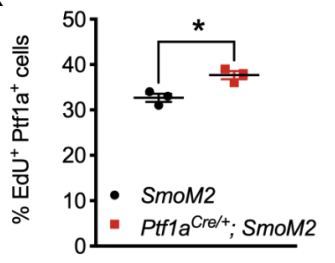

L

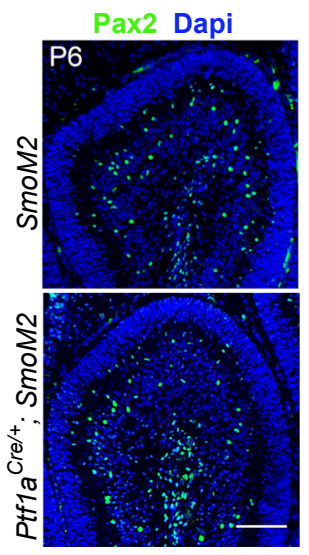

M

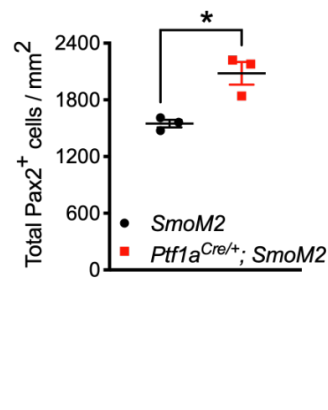

0

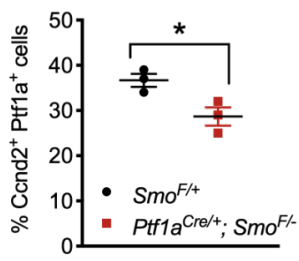

Figure 2, Li et al. 


\section{Figure 2. Shh signaling promotes Ptf1a+ progenitor proliferation and the expansion of}

\section{$\operatorname{Pax}^{+}$immature interneurons.}

(A-C) Ptfla and EdU staining in PWM of Smo ${ }^{\mathrm{F} /+}$ and Ptfla ${ }^{\mathrm{Cre} /+}$; Smo ${ }^{\mathrm{F} /}$ cerebella at P3 and P6. Arrowheads indicate cells positive for both EdU and Ptfla. Quantification of total Ptfla ${ }^{+}$cells in the PWM at P3 and P6 (B). The percentage of EdU ${ }^{+} / \mathrm{Ptfla}^{+}$double-positive cells relative to the total number of $\mathrm{Ptfla}^{+}$cells in PWM at P3 and P6 (C) is also quantified. $\mathrm{N}=3$ mice per group. Scale bars indicate $50 \mu \mathrm{m}$.

(D) Pax 2 and NeuN staining in sagittal sections of Smo ${ }^{\mathrm{F} /+}$ and Ptfla ${ }^{\mathrm{Cre} /+;}$ Smo ${ }^{\mathrm{F} /}$ cerebella. A higher magnification view of boxed regions is shown on the right. Abbreviations: WM, white matter; IGL, inner granule layer; ML, molecular layer. Scale bars indicate $100 \mu \mathrm{m}$.

(E-H) Quantitative analysis of Pax2+ cells in different regions of the cerebellum shown in D. $\mathrm{N}=3$ mice per group.

(I) Ptfla and EdU staining in PWM of SmoM2 and Ptfla ${ }^{\mathrm{Cre} /+}$; SmoM2 mice at P6. Arrowheads indicate cells positive for both EdU and Ptfla. Scale bars indicate $50 \mu \mathrm{m}$.

$(\mathrm{J}-\mathrm{K})$ Quantitative analysis of total Ptfla ${ }^{+}$cells $(\mathrm{J})$ and the percentage of EdU ${ }^{+} / \mathrm{Ptfla}^{+}$doublepositive cells relative to the total number of $\mathrm{Ptfla}^{+}$cells $(\mathrm{K})$ in PWM at P6.

(L) Pax2 staining in the ML of SmoM2 and Ptfla $\mathrm{Cre}^{+}$; SmoM2 mice at P6. Scale bars indicate $100 \mu \mathrm{m}$.

(M) Quantitative analysis of Pax2 $2^{+}$cells shown in L. $\mathrm{n}=3$ mice per group.

(O) Ptfla and Ccnd2 staining in PWM of SmoM2 and Ptfla ${ }^{\mathrm{Cre} /+}$; Smo ${ }^{\mathrm{F} /-}$ mice at P6. Arrowheads indicate cells co-expressing Ccnd2 and Ptfla. Scale bars indicate $50 \mu \mathrm{m}$.

(P) Quantitative analysis of the percentage of Ccnd2 and Ptfla double-positive cells relative to the total number of $\mathrm{Ptfla}^{+}$cells in PWM at P6. $\mathrm{N}=3$ mice per group.

All graphs displayed are mean \pm SEM. ${ }^{*} \mathrm{p} \leq 0.05,{ }^{*} \mathrm{p} \leq 0.01, * * * \mathrm{p} \leq 0.001$. n.s., not significant. 
bioRxiv preprint doi: https://doi.org/10.1101/2021.04.15.439999; this version posted October 14, 2021. The copyright holder for this preprint (which was not certified by peer review) is the author/funder. All rights reserved. No reuse allowed without permission.

A

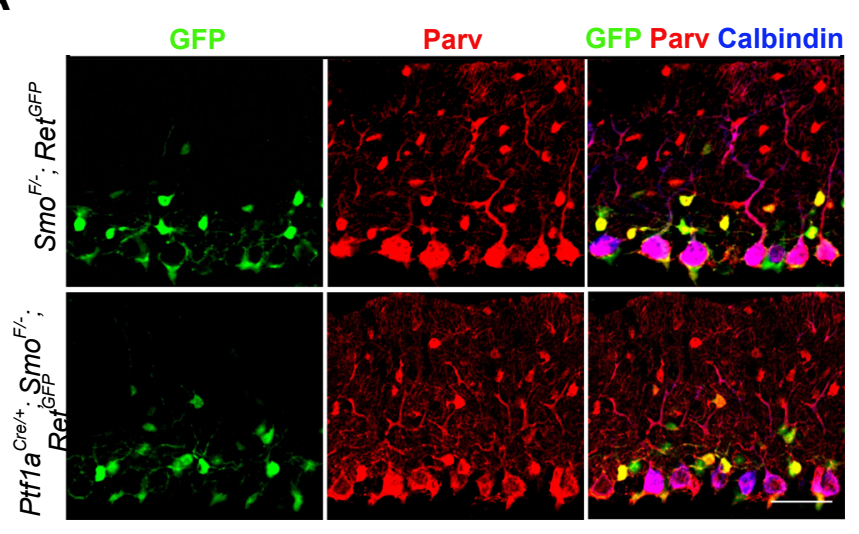

D

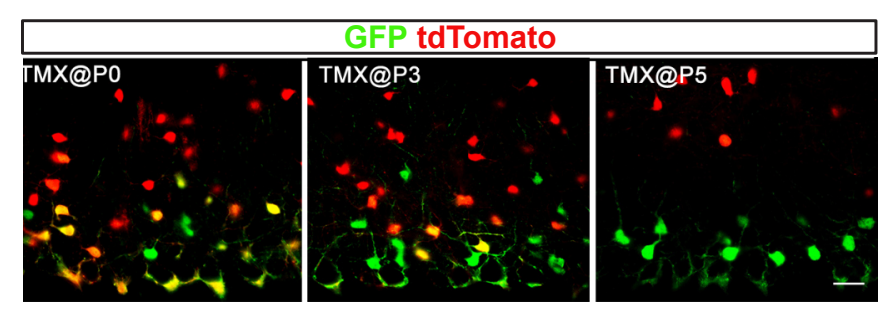

H

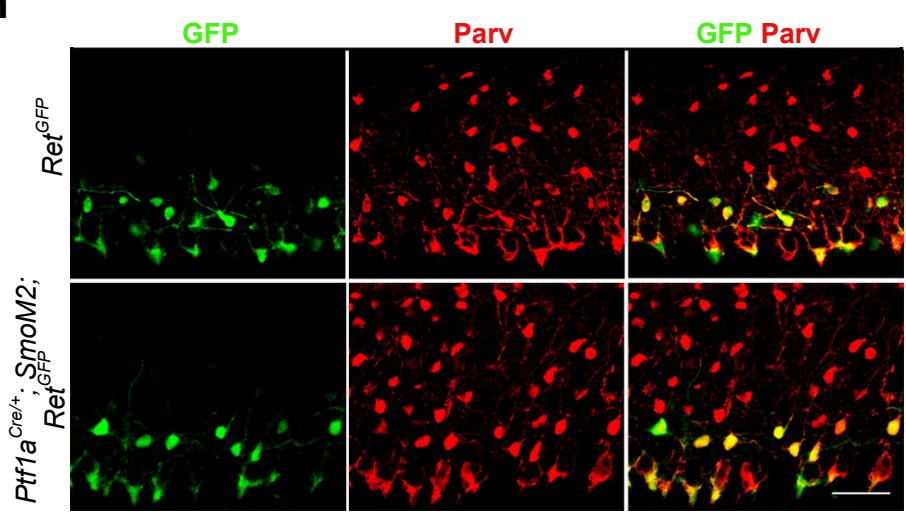

B

C

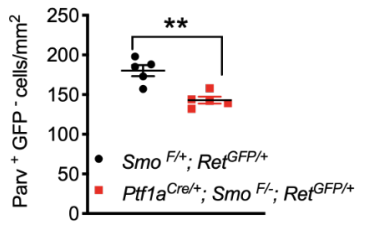

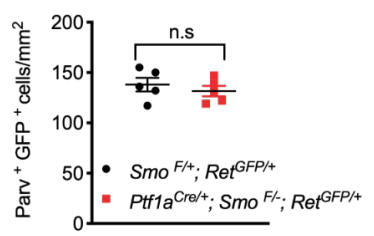

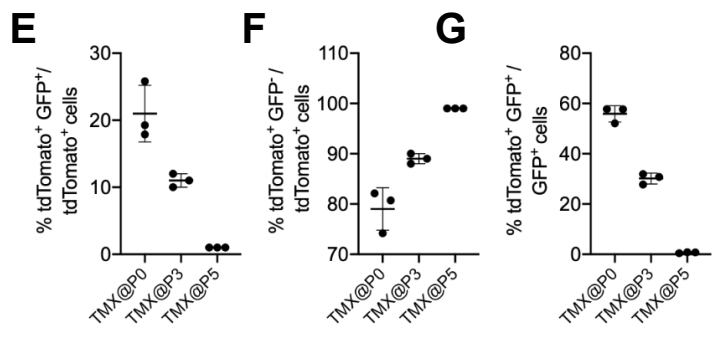

I

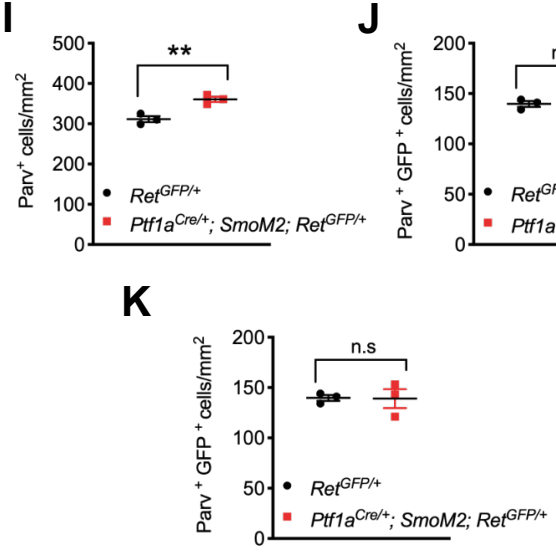

L

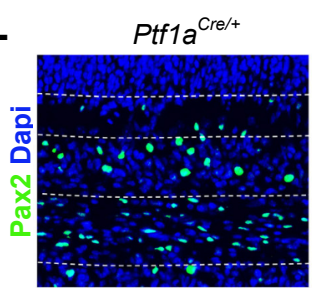

Q

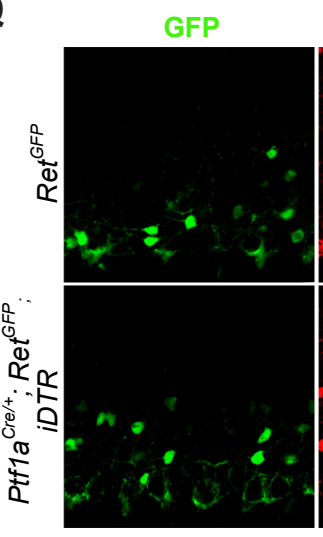

Ptf1a ${ }^{\text {Crelt}} ;$ iDTR $\quad \mathbf{M}$

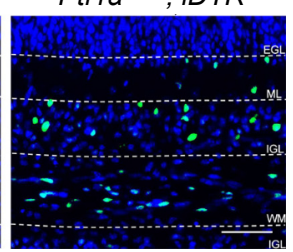

Parv

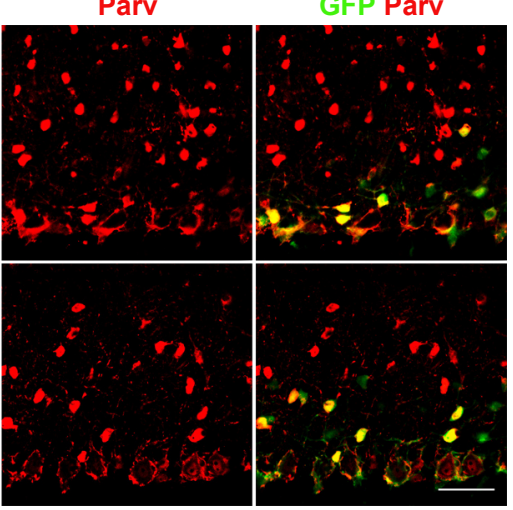

$\mathbf{N}$

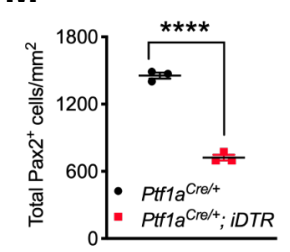

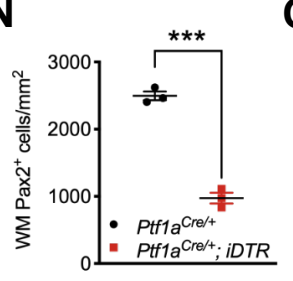

0

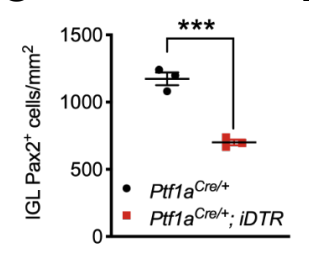

P

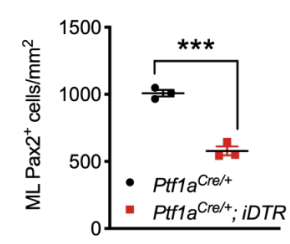

$\mathbf{R}$

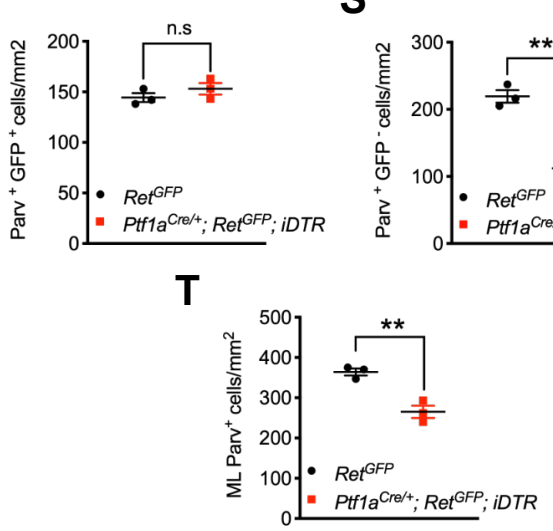

Figure 3, Li et al. 


\section{Figure 3. Shh signaling selectively regulates stellate cell pool size.}

(A) Cerebellar sections from P21 Smo ${ }^{\mathrm{F} /+} ; \operatorname{Ret}^{\mathrm{GFP} /+}$ and Ptfla $\mathrm{Crel+} ; \mathrm{Smo}^{\mathrm{Fl}-} ; \mathrm{Ret}^{\mathrm{GFP} /+}$ mice stained with antibodies against GFP, Parvalbumin and Calbindin.

(B-C) Quantitative analysis of $\mathrm{Parv}^{+} \mathrm{GFP}^{+}(\mathrm{B})$ and $\mathrm{Parv}^{+} \mathrm{GFP}^{-}$(C) cells shown in A. N= 5 mice per group.

(D) Cerebellar sections from P21 Ptfla ${ }^{C r e /+} ; R 26 R^{A i 9} ; R_{e t}{ }^{G F P /+}$ mice showing the extent of BC labeling (dtTomato ${ }^{+} \mathrm{GFP}^{+}$) following TMX induction at P0, P3 or P5.

(E-F) Quantitative analysis of the percentage of labeled BCs $\left(\mathrm{dtTomato}^{+} \mathrm{GFP}^{+}\right)$and $\mathrm{SCs}$

$\left(\mathrm{dtTomato}^{+} \mathrm{GFP}^{-}\right)$relative to total labeled $\left(\mathrm{dtTomato}^{+}\right)$cells.

(G) Quantitative analysis of the percentage of labeled BCs $\left(\mathrm{dtTomato}^{+} \mathrm{GFP}^{+}\right)$relative to total GFP+ BCs.

(H) Cerebellar sections from P21 $\operatorname{Ret}^{G F P /+}$ and Ptfla ${ }^{C r e /+} ; S m o M 2 ;$ Ret $^{G F P /+}$ mice stained with antibodies against GFP and Parvalbumin.

(I-K) Quantitative analysis of Parv+ (I), $\operatorname{Parv}^{+} \mathrm{GFP}^{+}(\mathrm{J})$ and $\mathrm{Parv}^{+} \mathrm{GFP}^{-}(\mathrm{K})$ cells shown in H. $\mathrm{N}=3$ mice per group.

(L) Cerebellar sections from P6 Ret ${ }^{G F P /+}$ and Ptfla ${ }^{C r e /+}$; iDTR mice showing Pax2 distribution (green) in EGL, IGL and WM following DT administration at P0-P2.

(M-P) Quantitative analysis of total Pax2+ cells (M) and Pax2+ cells in WM (N), IGL (O) and ML (P). N=3 mice per group.

(Q) Cerebellar sections from P21 $\operatorname{Ret}^{\mathrm{GFP} /+}$ and $\mathrm{Ptfla}^{\mathrm{Cre} /{ }^{+}}$; iDTR mice stained with antibodies against GFP and Parvalbumin.

(R-T) Quantitative analysis of $\operatorname{Parv}^{+} \mathrm{GFP}^{+}(\mathrm{R}), \mathrm{Parv}^{+} \mathrm{GFP}^{-}(\mathrm{S})$ and $\mathrm{Parv}^{+}(\mathrm{T})$ cells shown in A. $\mathrm{N}=3$ mice per group.

All graphs displayed are mean \pm SEM. ${ }^{*} \mathrm{p} \leq 0.05,{ }^{*} \mathrm{p} \leq 0.01, * * * \mathrm{p} \leq 0.001$. n.s., not significant. 
A

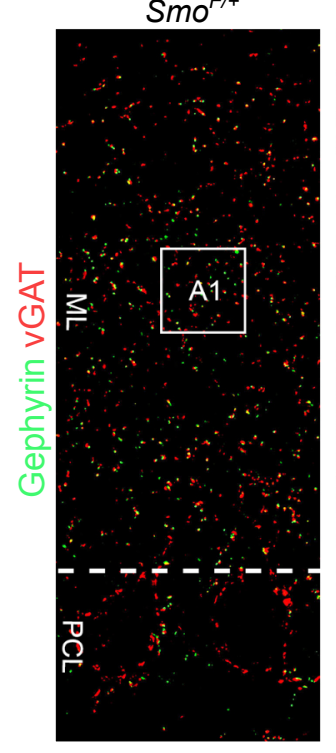

D

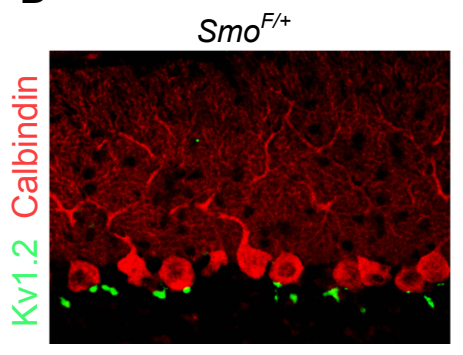

Ptf1a ${ }^{\mathrm{Cre} / \mathrm{t}} \cdot \mathrm{Smo} \mathrm{F}^{\mathrm{F} /}$
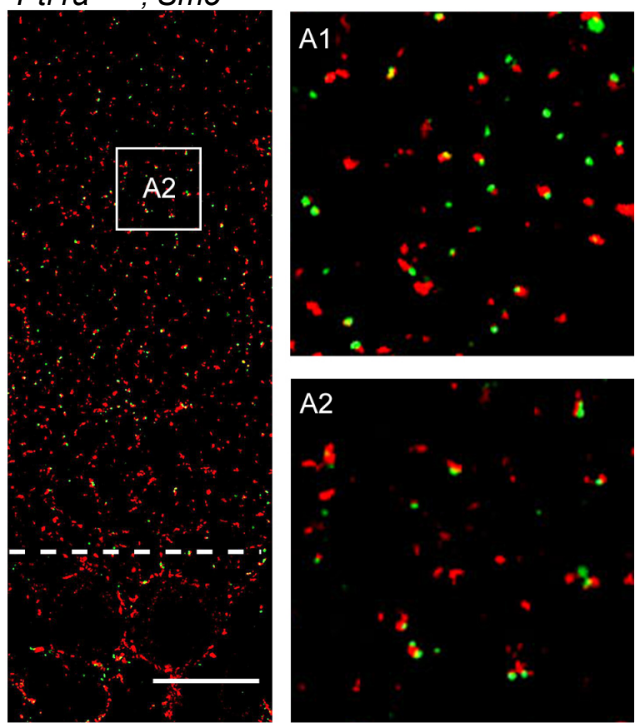

E
B
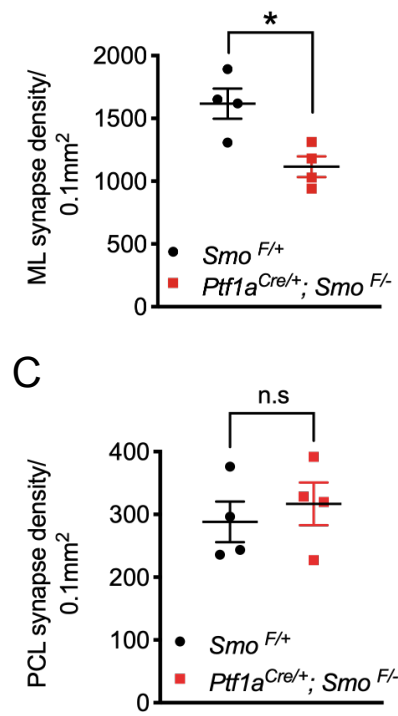
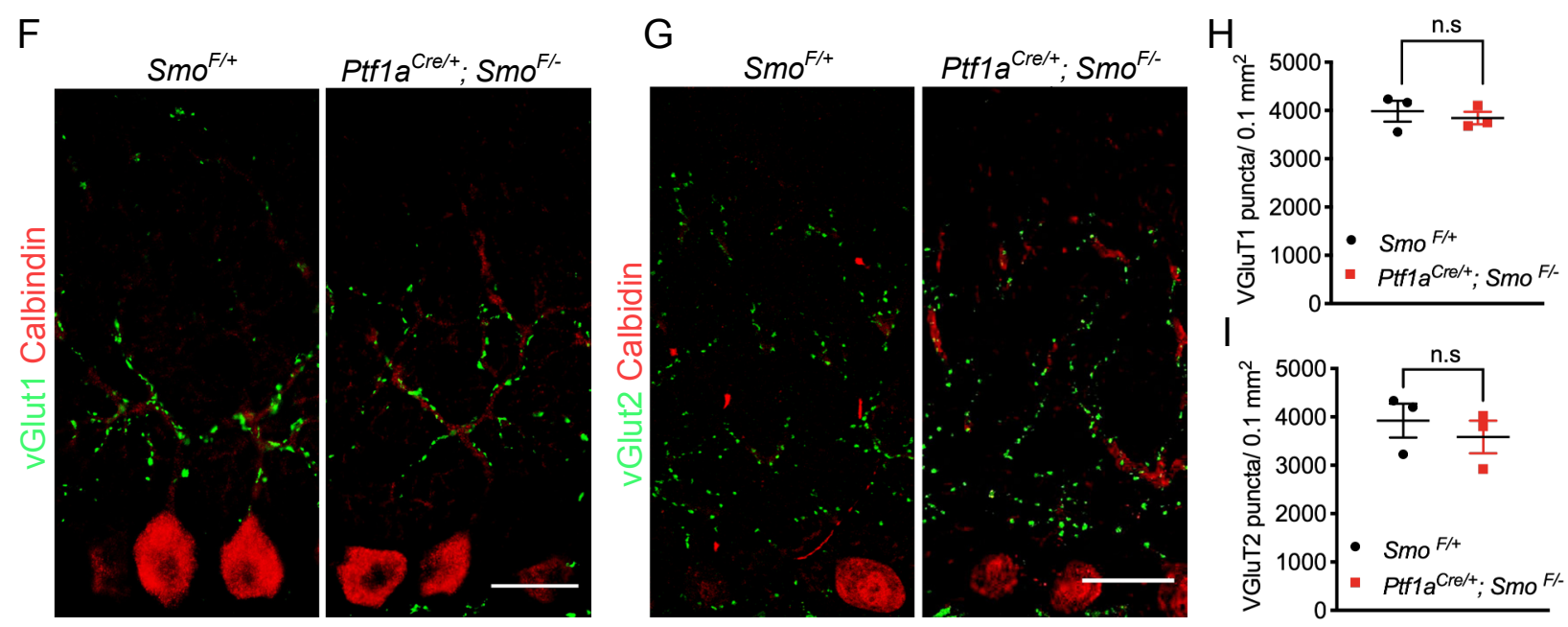

Figure 4, Li et al. 


\section{Figure 4. Loss of Shh-dependent stellate cells reduces ML GABAergic synapses.}

(A-A2) Cerebellar sections from P21 $\mathrm{Smo}^{\mathrm{F/+}}$ and $\mathrm{Ptfla}^{\mathrm{Cre} /+} ; \mathrm{Smo}^{\mathrm{F/}}$ mice stained with antibodies against vGAT and Gephyrin. A1 and A2 represent enlarged views of the boxed regions in A. ML, molecular layer. PCL, Purkinje cell layer. Scale bars indicate $25 \mu \mathrm{m}$.

(B-C) Quantitative analysis of vGAT and Gephyrin double-positive synapses in the ML (B) and PCL (C). N= 4 mice per group.

(D) Cerebellar sections from P21 Smo ${ }^{\mathrm{F} /+}$ and $\mathrm{Ptfla}^{\mathrm{Cre} /+}$; $\mathrm{Smo}^{\mathrm{F/}}$ mice stained with antibodies against Kv1.2 and calbindin. Scale bars indicate $50 \mu \mathrm{m}$.

(E) Quantitative analysis of Kv1.2 in PCL shown in D. N=4 mice per group.

(F-G) Cerebellar sections from P21 Smo ${ }^{\mathrm{F} /+}$ and $\mathrm{Ptfla}^{\mathrm{Cre} /+;} \mathrm{Smo}^{\mathrm{F/-}}$ mice stained with antibodies against vGluT1 (F), vGluT2 (G) and calbindin. Scale bars indicate $25 \mu \mathrm{m}$.

(H and I) Quantitative analysis of vGluT1 and vGluT2 positive puncta in the ML. N=3 mice per group.

All graphs displayed are mean \pm SEM. ${ }^{*} \mathrm{p} \leq 0.05, * * \mathrm{p} \leq 0.01, * * * \mathrm{p} \leq 0.001$. n.s., not significant. 

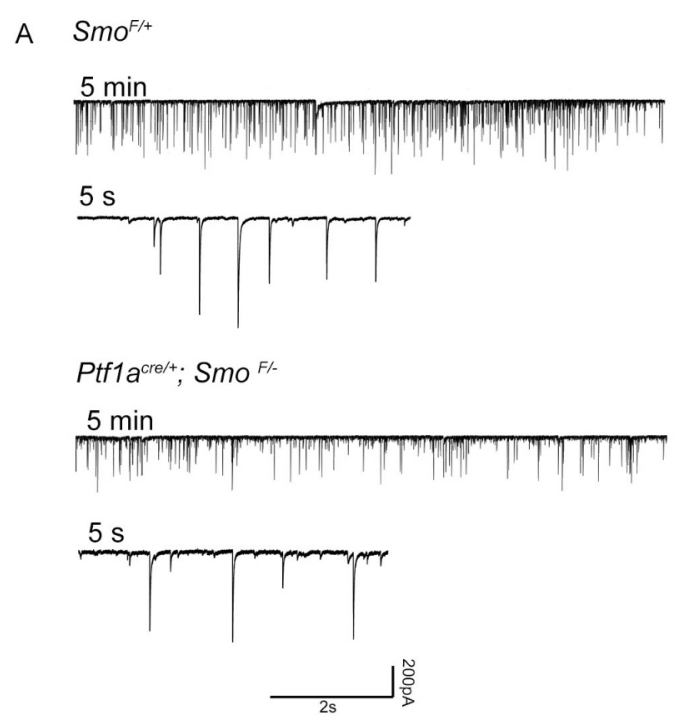

B

C
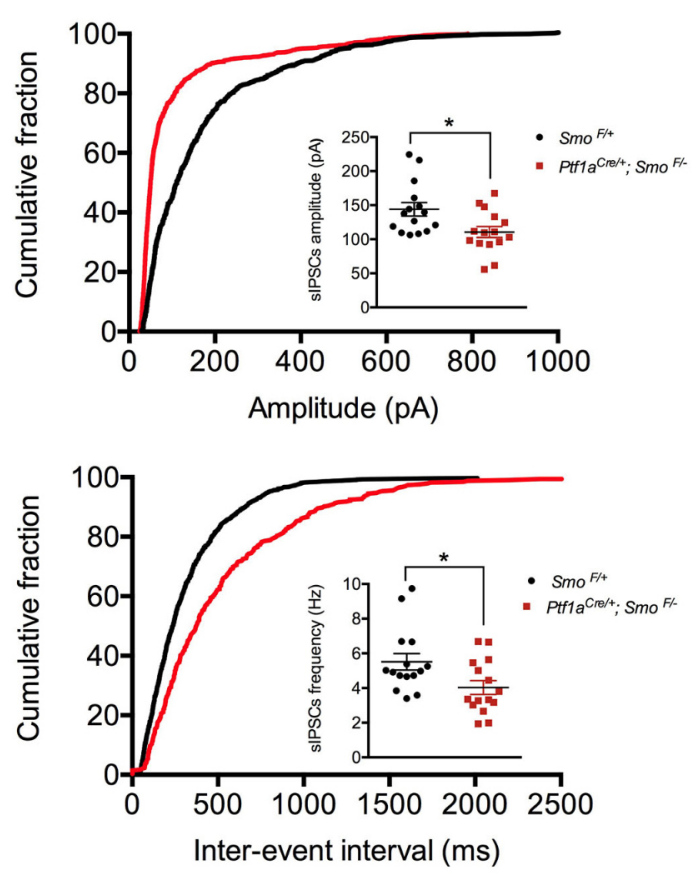

Figure 5, Li et al. 
Figure 5. Decreased amplitude and interevent interval of sIPSCs in $\mathrm{Ptfla}^{\mathrm{Cre} /+} ; \mathrm{Smo}^{\mathrm{F} /-}$ mutants.

(A) Representative traces of spontaneous IPSC recorded from $\mathrm{Smo}^{\mathrm{F/+}}$ and $\mathrm{Ptfla}^{\mathrm{Cre} /+}$; $\mathrm{Smo}^{\mathrm{F} /-}$ cerebellar Purkinje cells.

(B-C) Statistical analysis of sIPSCs amplitude (B) interevent interval (C). Each dot represents the mean of values obtained from 5 min recording sessions of individual PC. $\mathrm{N}=15$ cells from 11

Smo ${ }^{F /+}$ mice and $8 \mathrm{Ptfla}^{\mathrm{Cre} /+}$; Smo ${ }^{\mathrm{F} / \mathrm{-}}$ mice. Values represent mean $\pm \mathrm{SEM} .{ }^{*} \mathrm{p}<0.05$. 
A

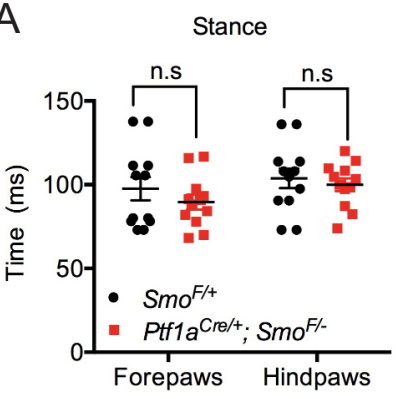

D

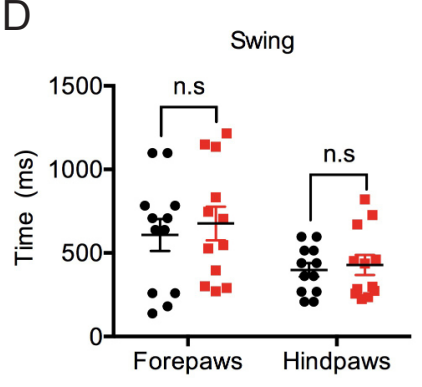

G

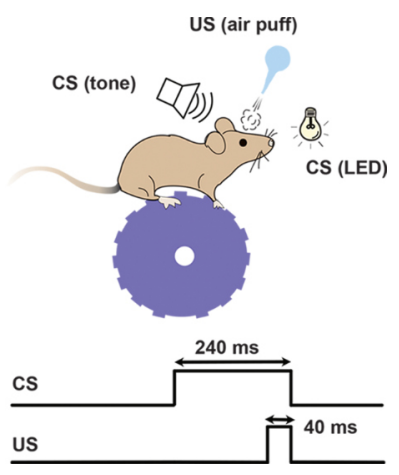

B

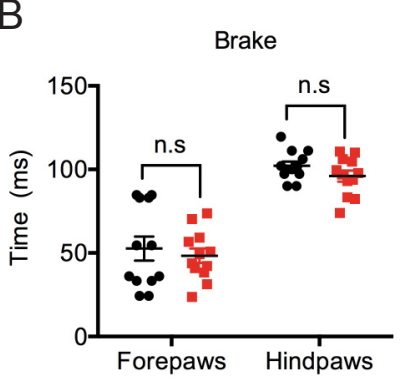

E

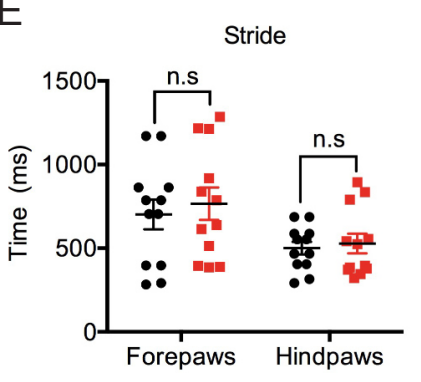

$\mathrm{H}$

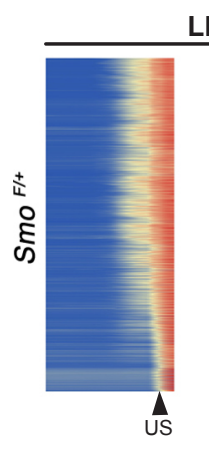

LED

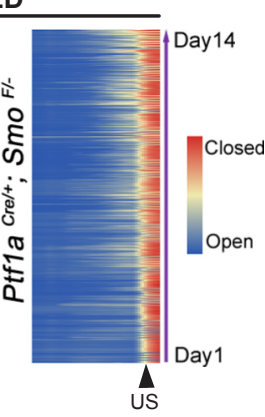

J

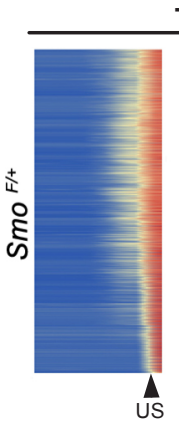

C

F
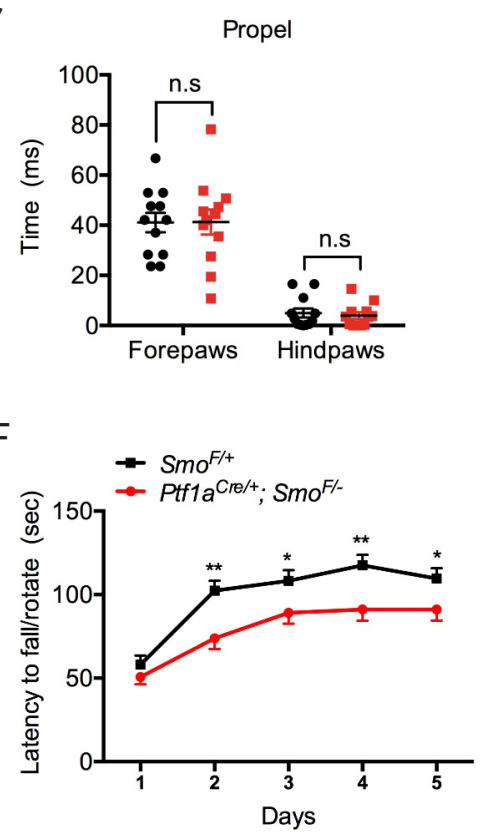

I

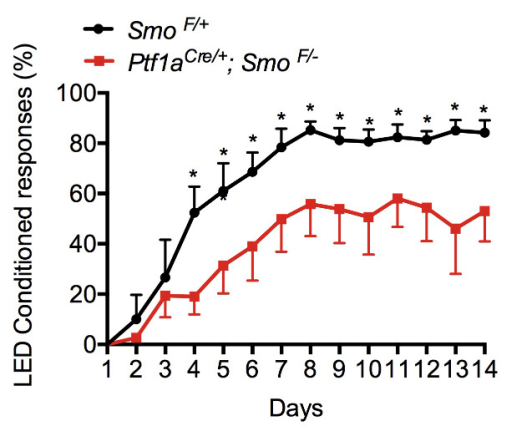

K

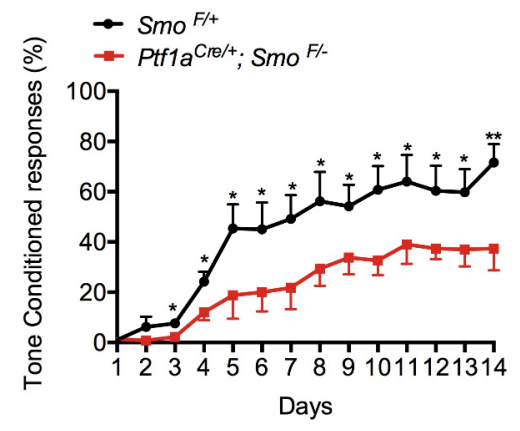

Figure 6, Li et al. 


\section{Figure 6. Shh-dependent SC pool is required for cerebellum-dependent motor learning but} not basic motor function.

(A-E) Quantitative gait analysis of adult $\mathrm{Smo}^{\mathrm{F/+}}$ and $\mathrm{Ptfla}^{\mathrm{Cre} /+}$; $\mathrm{Smo}^{\mathrm{F/-}}$ mice showing stance time (A), brake time (B), propel time (C), swing time (D) and stride time (E). $\mathrm{N}=12$ mice per group. (F) Accelerating rotarod test to measure latency to fall on five consecutive days in $\mathrm{Smo}^{\mathrm{F} /+}$ and $\mathrm{Ptfla}^{\mathrm{Cre} /+} ; \mathrm{Smo}^{\mathrm{F/}-}$ mice. $\mathrm{N}=30$ mice per group.

(G) Schematic of eyeblink conditioning system. The trial structure is consists of a $240 \mathrm{~ms}$ blue light (CS) or tone (CS) that precedes and co-terminates with a $40 \mathrm{~ms}$ air puff (US).

(H-J) Group averages of trial-by-trial eyelid closure over the entire 14 days of conditioning with LED (H) or tone (J) in $\mathrm{Smo}^{\mathrm{F/+}}$ and $\mathrm{Ptfla}^{\mathrm{Cre} /+} ; \mathrm{Smo}^{\mathrm{F/}}$ mice.

(I-K) The percentage of conditioned responses LED (I) or tone (K). $\mathrm{N}=5$ mice per group. All graphs displayed are mean \pm SEM. $* \mathrm{p}<0.05, * * \mathrm{p}<0.01$. n.s., not significant. 